Article

\title{
Pharmacophore Modeling and 3D-QSAR Study of Indole and Isatin Derivatives as Antiamyloidogenic Agents Targeting Alzheimer's Disease ${ }^{\S}$
}

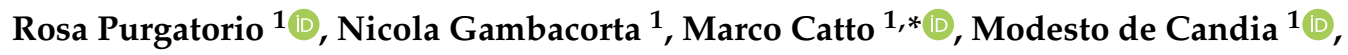 \\ Leonardo Pisani $^{1}{ }^{1}$, Alba Espargaró ${ }^{2}$, Raimon Sabaté ${ }^{2}{ }^{\circledR}$, Saverio Cellamare ${ }^{1}{ }^{\mathbb{D}}$, \\ Orazio Nicolotti ${ }^{1}$ (D) and Cosimo D. Altomare ${ }^{1}$ \\ 1 Department of Pharmacy-Pharmaceutical Sciences, University of Bari Aldo Moro, Via E. Orabona 4, \\ 70125 Bari, Italy; rosa.purgatorio@uniba.it (R.P.); nicola.gambacorta1@uniba.it (N.G.); \\ modesto.decandia@uniba.it (M.d.C.); leonardo.pisani@uniba.it (L.P.); saverio.cellamare@uniba.it (S.C.); \\ orazio.nicolotti@uniba.it (O.N.); cosimodamiano.altomare@uniba.it (C.D.A.) \\ 2 Institute of Nanoscience and Nanotechnology (IN2UB), Department of Physical Chemistry, Faculty of \\ Pharmacy, University of Barcelona, Joan XXIII 27-31, E-08028 Barcelona, Spain; aespargaro@ub.edu (A.E.); \\ raimon.sabate@gmail.com (R.S.) \\ * Correspondence: marco.catto@uniba.it; Tel.: +39-080-544-2780 \\ $\S$ This paper is dedicated to Prof. Francesco Campagna, who inspired and supervised this project before \\ his retirement.
}

Academic Editor: Derek J. McPhee

Received: 15 November 2020; Accepted: 4 December 2020; Published: 7 December 2020

\begin{abstract}
Thirty-six novel indole-containing compounds, mainly 3-(2-phenylhydrazono) isatins and structurally related $1 \mathrm{H}$-indole-3-carbaldehyde derivatives, were synthesized and assayed as inhibitors of beta amyloid $(\mathrm{A} \beta)$ aggregation, a hallmark of pathophysiology of Alzheimer's disease. The newly synthesized molecules spanned their $\mathrm{IC}_{50}$ values from sub- to two-digit micromolar range, bearing further information into structure-activity relationships. Some of the new compounds showed interesting multitarget activity, by inhibiting monoamine oxidases A and B. A cell-based assay in tau overexpressing bacterial cells disclosed a promising additional activity of some derivatives against tau aggregation. The accumulated data of either about ninety published and thirty-six newly synthesized molecules were used to generate a pharmacophore hypothesis of antiamyloidogenic activity exerted in a wide range of potencies, satisfactorily discriminating the 'active' compounds from the 'inactive' (poorly active) ones. An atom-based 3D-QSAR model was also derived for about $80 \%$ of 'active' compounds, i.e., those achieving finite $\mathrm{IC}_{50}$ values lower than $100 \mu \mathrm{M}$. The 3D-QSAR model (encompassing 4 PLS factors), featuring acceptable predictive statistics either in the training set $\left(n=45, \mathrm{q}^{2}=0.596\right)$ and in the external test set $\left(n=14, \mathrm{r}^{2}\right.$ ext $\left.=0.695\right)$, usefully complemented the pharmacophore model by identifying the physicochemical features mainly correlated with the $\mathrm{A} \beta$ anti-aggregating potency of the indole and isatin derivatives studied herein.
\end{abstract}

Keywords: isatin hydrazones; indole derivatives; antiamyloid agents; multitarget-directed ligands; 3D-QSAR

\section{Introduction}

Alzheimer's disease (AD) represents a major cause of illness and death in the world, especially in developed countries. Epidemiological data for United States account for almost 6 million Americans (aged $\geq 65$ ) currently hit by AD and 122,000 deaths in 2018 [1]. Most recent data for European Union, collected in the 2019 Yearbook of Alzheimer Europe organization, report about 9 million patients in 
2018, expected to increase to 10 and 16 million in 2025 and 2050, respectively, being Italy the country with the highest prevalence in population $(>2 \%)$ [2].

Unfortunately, current therapeutic approaches for $\mathrm{AD}$ remain still limited to the symptomatic treatment of memory impairment by acetylcholinesterase (AChE) inhibitors, namely donepezil, rivastigmine and galantamine, and of glutamate excitotoxicity by memantine. The lack of disease -resolving therapies for AD still fuels the research in this field, despite poor results so far obtained in clinical trials that have discouraged pharmaceutical industries to pursuing the research for new drugs. There are about 120 trials currently registered in US, almost half of which are from drug repurposing, and most of which addressing disease-modifying targets and/or immunotherapy [3]. On the other hand, alternative hypotheses for the treatment of $\mathrm{AD}$, considering the amyloid aggregation and toxicity, are still pursued mainly in academic settings. Despite many pitfalls registered in preclinical trials [4], there is still high interest in small molecules able to disrupt one or more steps in the amyloid cascade [5]. They may be resumed into a unitary approach known as amyloid hypothesis in $\mathrm{AD}$, encompassing beta amyloid $(A \beta)$ formation from APP precursor [6], A $\beta$ aggregation in the amyloid cascade from toxic oligomers to senile plaques [7], tau protein aggregation [8], and tau hyperphosphorylation [9] as potential therapeutic targets. Considering such a number of pathophysiological events, the so-called multitarget approach, aiming at hitting two or more of AD-related targets with a unique chemical entity, has become the "new paradigm" of researchers in the field [10].

In this context, our research programs have long been focused on multitarget approach having the antiamyloidogenic activity as the central feature [11-14]. Particularly, since 2010 we investigated the chemical space around the isatin/indolinone molecular core [15-17], disclosing potent in vitro inhibitors of beta amyloid aggregation, acting at different stages of the fibrillogenesis [18,19]. Herein, we further proceeded with a ligand-based approach to design novel inhibitors, and evaluated the antiamyloidogenic activity of such new compounds, as well as their potential as multitarget agents for AD. In parallel, we exploited the data of published compounds from our previous screening campaigns to generate a reliable pharmacophore, complemented with a 3D-QSAR model, for A $\beta$ aggregation inhibition by indole/indolone (mainly isatin hydrazones) derivatives.

Starting from the hit compound $\mathbf{1}[16,17]$ (Figure 1), the design strategy followed four main synthetic approaches aimed at (a) extending the exploration of the isatin-3-arylhydrazone scaffold; (b) simplifying the molecular structure to smaller isatin derivatives, possibly bearing $N$-substitution; (c) exploring bioisosteric indole derivatives, namely indole-3-carbaldehyde hydrazones; (d) investigating new indoline- and phthalimide-based analogues. 

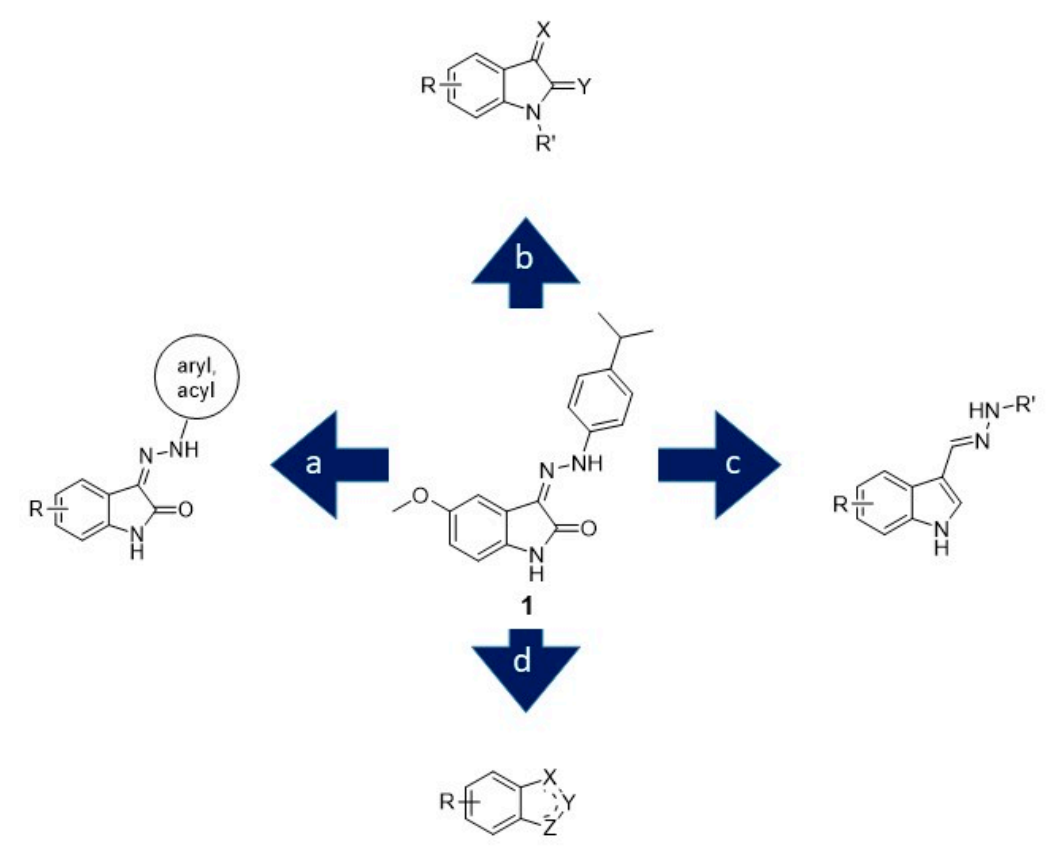

Figure 1. Ligand-based design of new inhibitors of amyloid aggregation.

\section{Results and Discussion}

\subsection{Chemistry}

Hydrazones 2-4 were prepared by condensation of suitable isatin with hydrazine hydrate in refluxing methanol, whereas arylhydrazones 5-9 were synthesized from isatin or $N$-methylisatin with the corresponding phenylhydrazines at room temperature (Scheme 1). The N-alkylation of 5-methoxyisatin was carried out through different methods giving the derivatives 10-15. The condensation of 10, 14 and 15 with 4-isopropylphenylhydrazine afforded compounds 16-18. Subsequently, 16 and 17 were demethylated with $\mathrm{BBr}_{3}$ [16] to 19 and 20, respectively (Scheme 2).

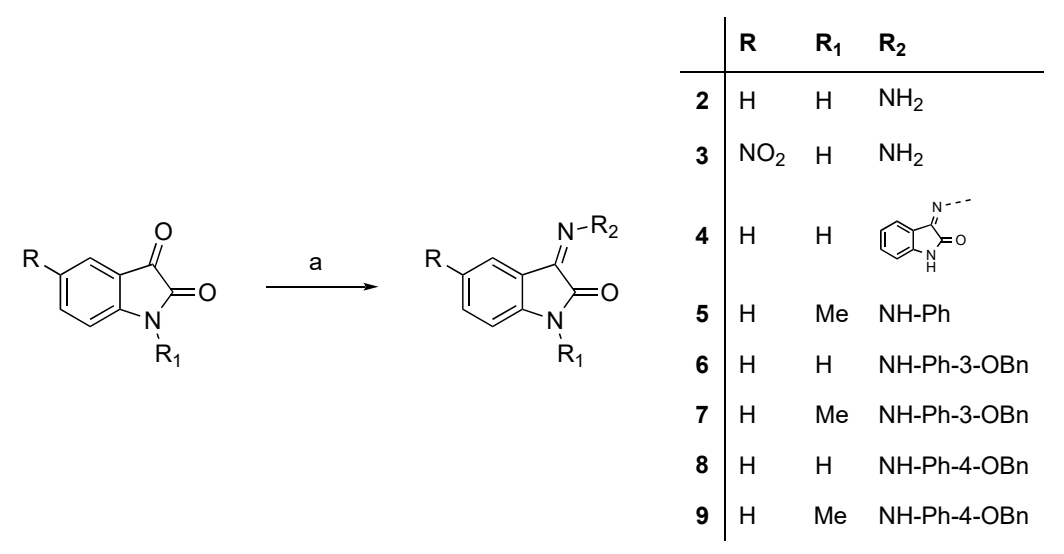

Scheme 1. Synthesis of hydrazones 2-9. Reagents and conditions: (a) $\mathrm{NH}_{2} \mathrm{NH}_{2} \bullet \mathrm{H}_{2} \mathrm{O}, \mathrm{MeOH}$, reflux or $\mathrm{ArNHNH}_{2}, \mathrm{MeOH}$, room temperature. 


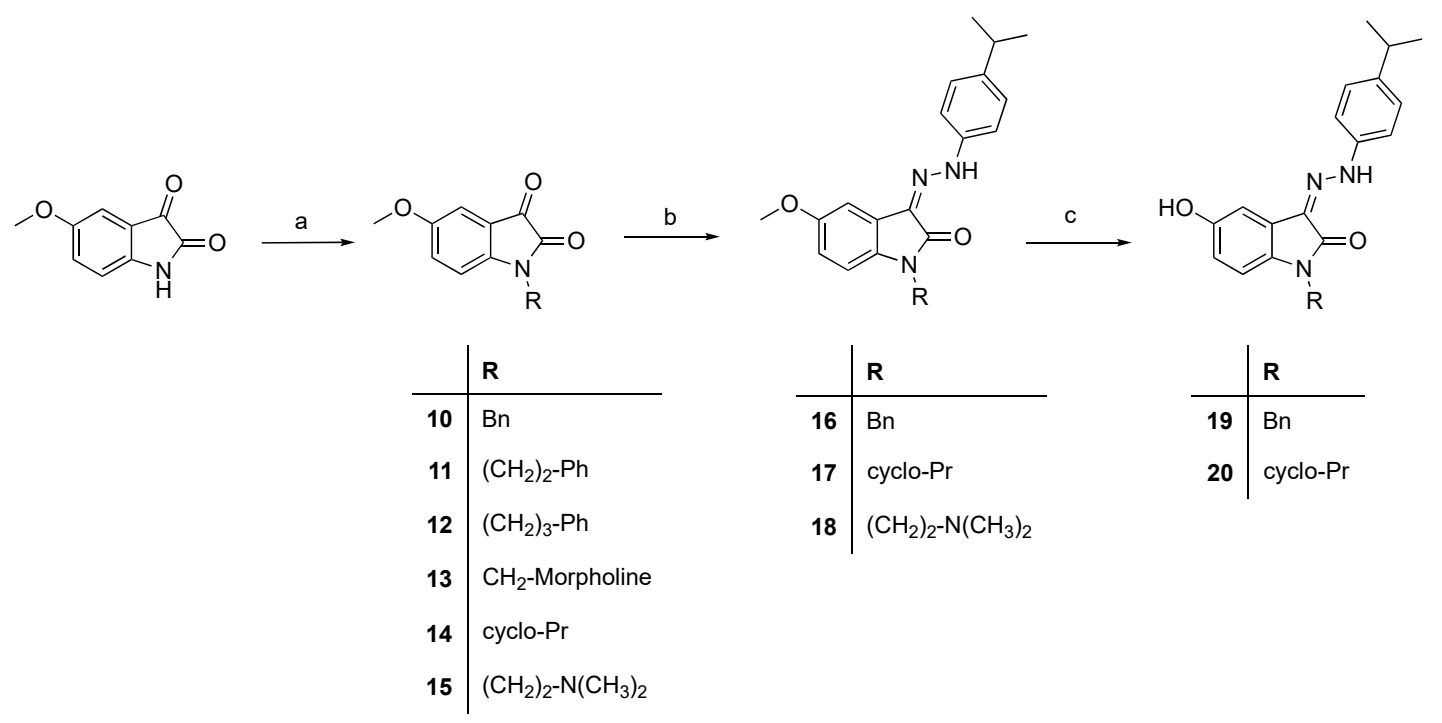

Scheme 2. Synthesis of compounds 10-20. Reagents and conditions: (a) DMF, $\mathrm{K}_{2} \mathrm{CO}_{3}$, 2-chloro- $N, N-$ dimethylethylamine hydrochloride, rt, or formaldehyde, morpholine, ethanol, reflux; (b) $\mathrm{MeOH}$, 4-isopropylphenylhydrazine, $\mathrm{rt}$; (c) $\mathrm{BBr}_{3}, \mathrm{CH}_{2} \mathrm{Cl}_{2},-70{ }^{\circ} \mathrm{C}$.

The azo-coupling of aryldiazonium salts 22a-c with indolin-2-one 21 [20] resulted in the formation of arylhydrazones 23-25 (Scheme 3). Compound $\mathbf{2 6}$ was synthesized by the condensation of 5-methoxyisatin with benzhydrazide as previously described [19] (Scheme 4), while the indolin-3-one 27 was obtained from indoxyl acetate and 4-hydroxybenzaldehyde in acidic conditions (Scheme 5).

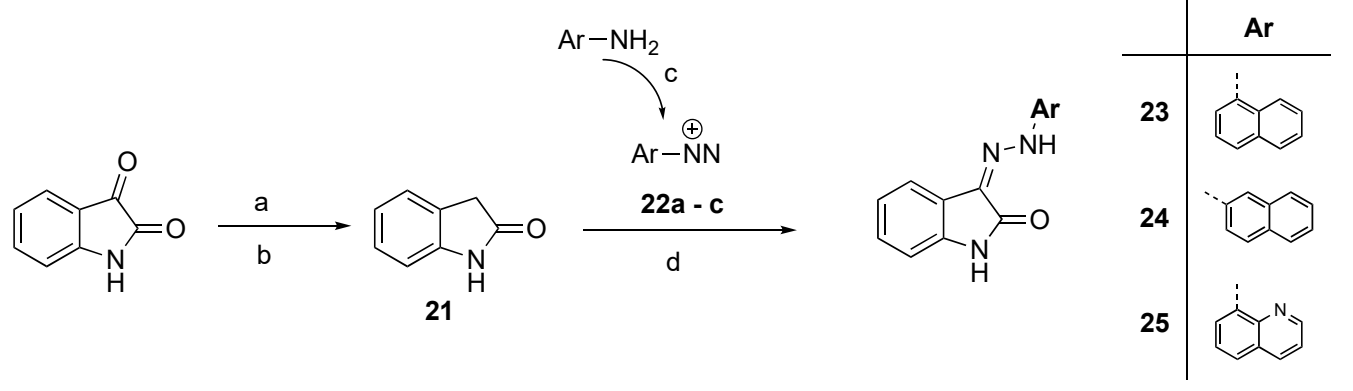

Scheme 3. Synthesis of 23-25. Reagents and conditions: (a) $\mathrm{NH}_{2} \mathrm{NH}_{2} \bullet \mathrm{H}_{2} \mathrm{O}, \mathrm{EtOH}$; (b) $\mathrm{NaOH}, \mathrm{EtOH}$, $\mathrm{H}_{2} \mathrm{O}$, reflux; (c) $\mathrm{NaNO}_{2}, \mathrm{H}_{2} \mathrm{O}, \mathrm{HCl} 6 \mathrm{~N}, 0^{\circ} \mathrm{C}$; (d) $\mathrm{MeOH}, \mathrm{CH}_{3} \mathrm{COONa}, 0^{\circ} \mathrm{C}$.

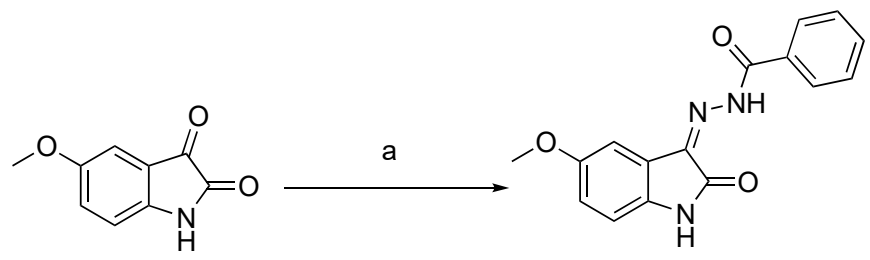

26

Scheme 4. Synthesis of compound 26. Reagents and conditions: (a) benzhydrazide, methanol, rt. 


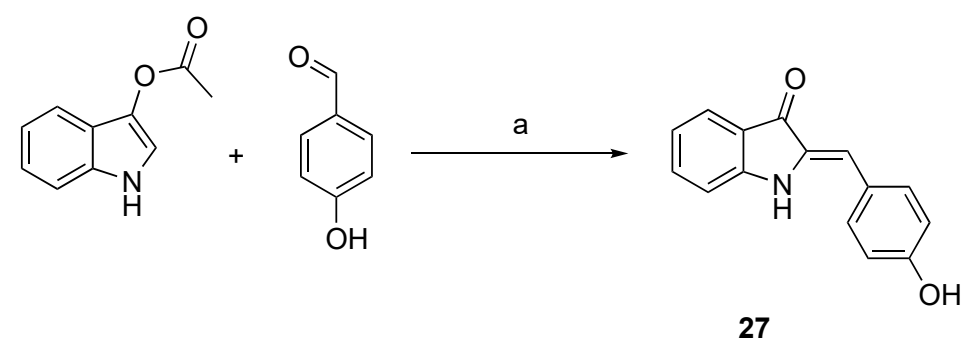

Scheme 5. Synthesis of 27. Reagents and conditions: (a) $\mathrm{MeOH}, \mathrm{HCl}$ conc., reflux, $\mathrm{N}_{2}$.

The synthesis of indole-3-carbaldehyde hydrazones 28-36 was accomplished, according to previously reported procedures [19], by condensation of the R-substituted indole-3-carbaldehyde with arylhydrazine at room temperature (Scheme 6). The reaction of 37 with 4 -isopropylphenylhydrazine, in the same conditions, afforded phthalimide monohydrazone 38 (Scheme 7).

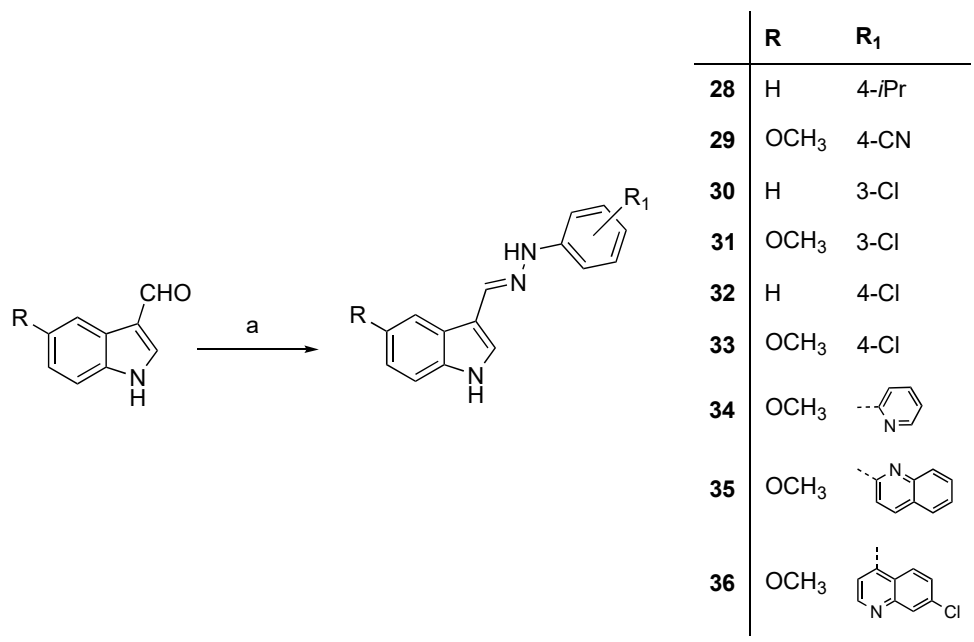

Scheme 6. Synthesis of compounds 28-36. Reagents and conditions: (a) arylhydrazine $\mathrm{HCl}, \mathrm{MeOH}$ or $\mathrm{EtOH}, \mathrm{rt}$.

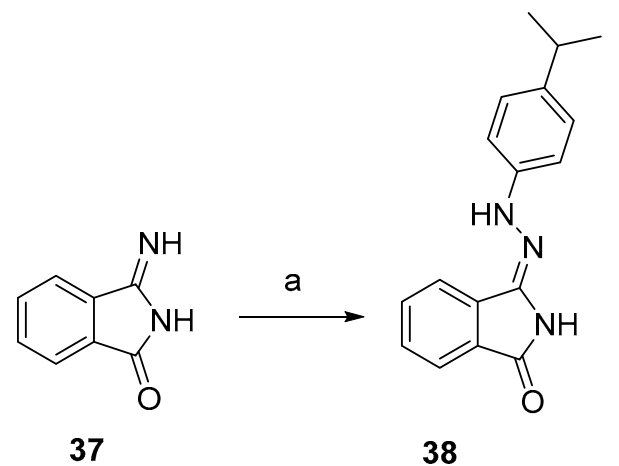

Scheme 7. Synthesis of compound 38. Reagents and conditions: (a) 4-isopropylphenylhydrazine, $\mathrm{MeOH}$, rt.

Compounds 40 and 41 were synthesized from 39, prepared under Vilsmeier conditions [21], with the appropriate phenylhydrazine in an acid-catalyzed reaction (Scheme 8). Finally, the synthesis of the indolinone 43 was carried out under neat conditions starting from indoxyl acetate and dihydroxyquinolinedione 42 [22] (Scheme 9). Compounds 44 [23] and 45 [24] were prepared according to the quoted references. 
<smiles>[R]c1ccc(N/N=C/c2[nH]c3ccc(Br)cc3c2Cl)cc1</smiles>

Scheme 8. Synthesis of 40 and 41. Reagents and conditions: (a) DMF, $\mathrm{POCl}_{3}$; (b) R-phenylhydrazine, acetic acid, $\mathrm{EtOH}, 0{ }^{\circ} \mathrm{C}$.<smiles>O=C1Nc2ccccc2C(=O)C1(O)O</smiles>

42<smiles>CC(=O)Oc1c[nH]c2ccccc12</smiles>

a

Scheme 9. Synthesis of 43 . Reagents and conditions: (a) neat, $120^{\circ} \mathrm{C}$.

\subsection{Inhibition of $A \beta_{40}$ Aggregation}

All the newly prepared compounds were tested in a routine in vitro assay of inhibition of $A \beta_{40}$ self-aggregation [25]. For the sake of clarity, compounds and related data are listed in four tables, according to the design strategy above mentioned. Table 1 collects all the compounds prepared with the aim of extending the exploration of SAR around the arylhydrazone substituent. The most potent compounds were found among the $N$-substituted analogues of $\mathbf{1}$, namely 18 and 19 , while $N$-cyclopropyl derivative 20 resulted poorly active. Naphthylhydrazones $\mathbf{2 3}$ and $\mathbf{2 4}$ were also found highly active, while the quinoline derivative 25, isoster of 23, resulted less potent and the benzhydrazide 26 almost inactive. The 5-substitution appeared to have contrasting effects on potency; it is worthy of note that 5-methoxy analogue of 5-hydroxy derivative 20, previously published [19], returned very higher potency than the latter, with $\mathrm{IC}_{50}$ in the submicromolar range. 
Table 1. Inhibition data of new isatin derivatives 18-20 and 23-26.<smiles>[R2]N/N=C1\C(=O)N([R7])c2ccc([R])cc21</smiles>

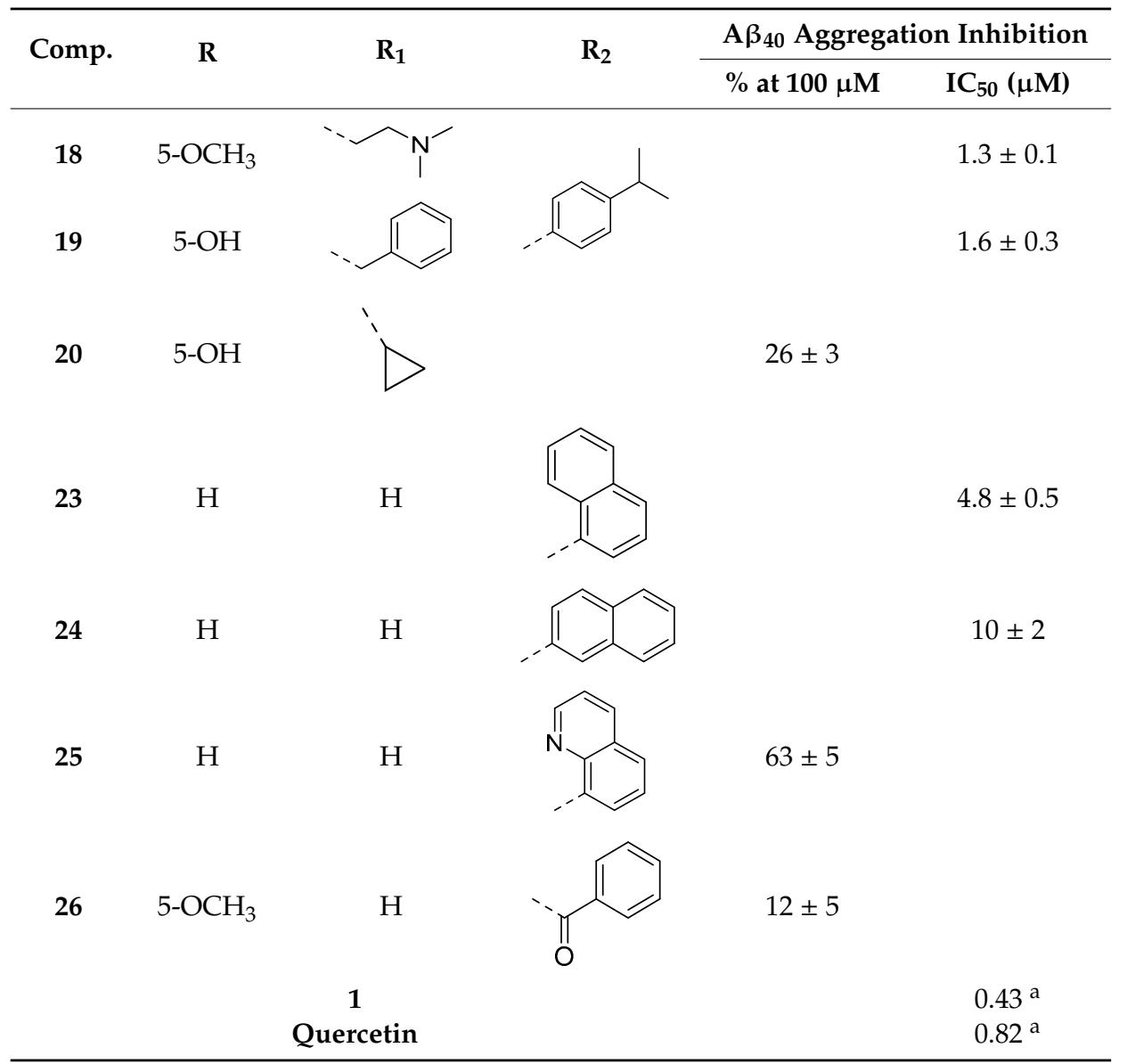

${ }^{\text {a }}$ Data taken from [17]. Values are mean $\pm \operatorname{SEM}(n=3)$.

The molecular simplification around the isatin core led to compounds listed in Table 2. In all cases, activities were quite far from reference compound 1, particularly for unsubstituted hydrazones 2 and 3. Also in this series, $N$-substituted derivatives of isatin scored the best results, with potencies increasing from benzyl to phenethyl and 3-phenylpropyl $(\mathbf{1 0}<\mathbf{1 1}, \mathbf{1 2})$. Disappointingly, the morpholine derivative 13, prepared as the Mannich base of 5-methoxyisatin, proved to be a weak inhibitor of aggregation, as well as the cyclopropyl derivative 14. The substitution at the position 2 of isatin, leading to condensation products 27 and 44, aimed at probing steric effects in this position. Both compounds retained only a weak activity against $A \beta$ aggregation. 
Table 2. Inhibition data of new isatin derivatives $2,3,10-14,27$ and 44.

12

A major objective of this work was to investigate the isosteric variation of hydrazone derivatization from isatin to indole, afforded by condensing indole-3-carbaldehyde with selected arylhydrazines. The A $\beta$ aggregation data in Table 3 account for a satisfactory activity profile, partially associated to the favorable effects of 5-methoxy substituent, and likely depending upon the hydrophobic feature of the arylhydrazine moiety. Both isopropyl and chlorine substituents warranted good potencies compared to nitrile, the 4-chloro isomer 32 being the most potent of the molecular subset. As a confirmation of the favorable hydrophobic effects, quinoline derivatives 35 and 36 were much more potent than pyridine congener 34. As already noticed for compound 26, benzhydrazide 45 lost any antiaggregating activity. 
Table 3. Inhibition data of new indole-3-carbaldehyde hydrazones 28-36 and 45.<smiles>[R]N/N=C/c1c[nH]c2ccc([R])cc12</smiles>

\begin{tabular}{|c|c|c|c|c|}
\hline \multirow{2}{*}{ Comp. } & \multirow{2}{*}{$\mathbf{R}$} & \multirow{2}{*}{$\mathbf{R}_{1}$} & \multicolumn{2}{|c|}{$A \beta_{40}$ Aggregation Inhibition } \\
\hline & & & $\%$ at $100 \mu \mathrm{M}$ & $\mathrm{IC}_{50}(\mu \mathrm{M})$ \\
\hline 28 & $\mathrm{H}$ & & & $18 \pm 2$ \\
\hline 29 & $5-\mathrm{OCH}_{3}$ & & $56 \pm 1$ & \\
\hline 30 & $\mathrm{H}$ & & & $13 \pm 2$ \\
\hline 31 & $5-\mathrm{OCH}_{3}$ & & & $9.2 \pm 0.7$ \\
\hline 32 & $\mathrm{H}$ & & & $8.4 \pm 0.6$ \\
\hline 33 & $5-\mathrm{OCH}_{3}$ & & & $22 \pm 2$ \\
\hline 34 & $5-\mathrm{OCH}_{3}$ & & $20 \pm 2$ & \\
\hline 35 & $5-\mathrm{OCH}_{3}$ & & & $12 \pm 2$ \\
\hline 36 & $5-\mathrm{OCH}_{3}$ & & & $13 \pm 1$ \\
\hline 45 & $5-\mathrm{OCH}_{3}$ & & 0 & \\
\hline
\end{tabular}

Finally, a few isomers of isatin were explored in order to ascertain the effects of modification of the core structure, while maintaining the arylhydrazone moiety (Table 4 ). Only compound 40 gave a measurable $\mathrm{IC}_{50}$ equal to $25 \mu \mathrm{M}$, while 4-isopropyl derivatives 38 and 41 were found less potent and the condensation product 43 was almost inactive. 
Table 4. Inhibition data of new derivatives $38,40,41$ and 43 .

Comp.

\subsection{Cytoprotection from Tau Toxicity}

The deposition of aggregates of hyperphosphorylated tau protein constitutes the intracellular neurofibrillary tangles, a major histological evidence of AD. The role of tau hyperphosphorylation and aggregation in $\mathrm{AD}$ has established both of them as a target for therapeutic interventio [8], although only $\mathrm{N}, \mathrm{N}, \mathrm{N}^{\prime}, \mathrm{N}^{\prime}$-tetramethyl-10H-phenothiazine-3,7-diaminium (TRX0237, leucomethylthioninium), the reduced form of methylene blue dye, acting as an inhibitor of tau aggregation, has reached the clinical phase III [26]. In recent years, some of us developed an efficient cell-based assay of tau aggregation, a simple and inexpensive method that provides a straightforward assay to evaluate the putative anti-aggregation capacity of small molecules [27-29]. This method relies on the use of bacteria overexpressing amyloid-prone proteins to monitor the amyloid aggregation, thus constituting a physiologically relevant model. In particular, it exploits amyloid properties of the inclusions bodies (IBs) formed by tau full-length protein in bacteria stained by thioflavin $\mathrm{S}$ (ThS), a specific amyloid dye, to address the bacterial amyloid aggregation and the effect of anti-amyloid compounds in this polymerization process.

From a randomized screening of our in-house library, including four amyloid aggregation inhibitors S22, S23, S34 and S35 coming from a previous work [16], isatin hydrazones S23 and S35 emerged as interesting inhibitors of tau cytotoxicity, with $\mathrm{IC}_{50}$ values in the micromolar range (Table 5). We then decided to prepare and test, as analogues of S23, the bis-isatin hydrazone 4 and the 5-unsubstituted derivative 5, along with the 5-unsubstituted congeners of $\mathbf{S 3 5}$ and S34, i.e., compounds 6 and 8. To confirm the effects of $\mathrm{N}$-substitution at the isatin nitrogen, we also prepared and tested their $\mathrm{N}$-methyl derivatives $\mathbf{7}$ and $\mathbf{9}$. From the screening, isatin hydrazone $\mathbf{5}$ emerged as a potent inhibitor of tau aggregation $\left(\mathrm{IC}_{50} 4.6 \mu \mathrm{M}\right.$ ), with slightly higher potency than its 5-methoxy congener S23. The remaining new compounds scored low inhibition values, despite the limited structural variations performed. On the other hand, the assay on $A \beta_{40}$ aggregation disclosed the strong inhibitory potency of $\mathrm{N}$-methyl derivatives $\mathbf{7}$ and $\mathbf{9}$, with $\mathrm{IC}_{50} \mathrm{~s}$ in the low to submicromolar range. Compared with their reference analogues S35 and S34, where the activities of meta were slightly higher than para congeners, $\mathbf{6}$ and $\mathbf{8}$ showed an opposite trend, and both resulted strongly weaker than their 
corresponding $\mathrm{N}$-methylated derivatives. Overall, compound 9 emerged as the most potent inhibitor of $\mathrm{A} \beta_{40}$ aggregation within the whole series of tested herein.

Table 5. Inhibition of $\beta$-amyloid and tau aggregation.

\begin{tabular}{|c|c|c|c|c|c|}
\hline \multirow{2}{*}{ Code } & \multirow{2}{*}{ Structure } & \multicolumn{2}{|c|}{$A \beta_{40}$ Inhibition } & \multicolumn{2}{|c|}{ Tau Inhibition ${ }^{a}$} \\
\hline & & $\%$ at $100 \mu \mathrm{M}$ & $\mathrm{IC}_{50}(\mu \mathrm{M})$ & $\%$ at $10 \mu \mathrm{M}$ & $\mathrm{IC}_{50}(\mu \mathrm{M})$ \\
\hline $\mathrm{S} 22 \mathrm{~b}$ & & $-c$ & & $15 \pm 3$ & \\
\hline $\mathrm{S} 23^{b}$ & & 52 & & & $7.7 \pm 1.0$ \\
\hline S34 b & & 20 & & $16 \pm 2$ & \\
\hline S35 b & & 44 & & & $10 \pm 2$ \\
\hline 4 & & $31 \pm 3$ & & $17 \pm 2$ & \\
\hline 5 & & & $22 \pm 2$ & & $4.6 \pm 0.7$ \\
\hline 6 & & $45 \pm 6$ & & $14 \pm 2$ & \\
\hline 7 & & & $2.0 \pm 0.3$ & $19 \pm 2$ & \\
\hline 8 & & $69 \pm 3$ & & $35 \pm 2$ & \\
\hline 9 & & & $0.95 \pm 0.04$ & $20 \pm 2$ & \\
\hline
\end{tabular}

a From cell-based assay. ${ }^{\mathrm{b}}$ Compounds and their data of $\beta$-amyloid aggregation are taken from ref. [16] and presented in Supplementary Materials. Values are mean $\pm \operatorname{SEM}(n=3)$ in in vitro assay. ${ }^{\mathrm{C}}$ No inhibition at $100 \mu \mathrm{M}$ concentration. 


\subsection{Evaluation of Multitarget Activity}

The benefits of multitarget approach for the treatment of neurodegenerative diseases are widely recognized, although the pharmacological proof of concept is still controversial [10]. Our research has devoted large attention to dual inhibitors of cholinesterases (ChEs) and monoamine oxidases (MAOs), two major targets in neurodegeneration [30-32]. Acetyl-(AChE) and butyrylcholinesterase (BChE) are responsible for the hydrolysis of neurotransmitter acetylcholine, particularly in brain regions involved in learning and memory processes. AChE inhibitors still remain the first options for the symptomatic treatment of cognitive impairment in AD. Monoamine oxidase isoforms A (MAO A) and B (MAO B) are mitochondrial enzymes responsible for oxidative degradation of amine neurotransmitters and xenobiotics. Selective MAO A inhibitors are second-line drugs in the treatment of depression and mood disorders, while MAO B-selective inhibitors are used in the therapy of Parkinson's disease and have neuroprotective effects. Isatin is an endogenous biofactor, metabolically derived from indole, largely present in the CNS [33]; isatin derivatives are recognized bioactive molecules for many neurological diseases [34]. 5-Substituted isatins have been described as potent MAO inhibitors [35,36] and recently, $\mathrm{N}$-substituted 3-acylhydrazones of isatin showed interesting dual AChE-MAO B inhibitory activities [37].

The above-cited evidences prompted us to extend the investigation of biological activity to ChEs and MAOs, by testing a limited number of isatin and indole derivatives in in vitro inhibition of human ChEs and MAOs. Compounds were selected according to the following criteria: (a) the most potent inhibitors of $A \beta_{40}$ aggregation within the structural classes collected in Tables 1-3 and 5 (i.e., compounds $\mathbf{9}$, including its isomers $\mathbf{6 - 8}$ for the exploration of putative substitution-activity relationships, 18, 19, 23, 11 and 32); (b) the most potent inhibitor of tau toxicity (5); (c) compounds bearing a basic nitrogen, in order to get an efficient interaction with the catalytic site of ChEs, either at the arylhydrazone moiety (35) or Mannich bases at the isatin nitrogen (18 and 13).

The data in Table 6 assessed a weak inhibitory potency in AChE inhibition $(<50 \%$ at $10 \mu \mathrm{M})$, with the valuable exception of benzyloxy isomers 6 and 8 ( $\mathrm{IC}_{50} \mathrm{~s}$ in the low micromolar range). Disappointingly, none of compounds with basic substituents was found active. As for BChE inhibition, all compounds were ineffective (data not shown).

Table 6. Inhibition data of acetylcholinesterase and monoamine oxidases.

\begin{tabular}{|c|c|c|c|c|c|c|}
\hline \multirow{2}{*}{ Comp. } & \multicolumn{2}{|c|}{$h \mathrm{AChE}^{\mathrm{a}}$} & \multicolumn{2}{|c|}{$h \mathrm{MAO} \mathrm{A}^{\mathrm{a}}$} & \multicolumn{2}{|c|}{$h \mathrm{MAO} \mathrm{B}^{\mathrm{a}}$} \\
\hline & $\%$ Inhib. at $10 \mu \mathrm{M}$ & $\mathrm{IC}_{50}(\mu \mathrm{M})$ & $\%$ Inhib. at $10 \mu \mathrm{M}$ & $\mathrm{IC}_{50}(\mu \mathrm{M})$ & $\%$ Inhib. at $10 \mu \mathrm{M}$ & $\mathrm{IC}_{50}(\mu \mathrm{M})$ \\
\hline 5 & $37 \pm 1$ & & & $0.52 \pm 0.04$ & & $3.6 \pm 0.7$ \\
\hline 6 & & $4.2 \pm 0.8$ & $23 \pm 5$ & & $22 \pm 4$ & \\
\hline 7 & $48 \pm 3$ & & $29 \pm 3$ & & $41 \pm 1$ & \\
\hline 8 & & $3.9 \pm 0.5$ & $8 \pm 3$ & & $36 \pm 4$ & \\
\hline 9 & $48 \pm 2$ & & $15 \pm 3$ & & & $4.0 \pm 0.4$ \\
\hline 18 & $23 \pm 1$ & & $31 \pm 4$ & & $47 \pm 2$ & \\
\hline 19 & $31 \pm 1$ & & $18 \pm 4$ & & $46 \pm 5$ & \\
\hline 23 & $40 \pm 3$ & & & $7.1 \pm 0.3$ & & $5.3 \pm 0.3$ \\
\hline 11 & $47 \pm 5$ & & $20 \pm 4$ & & & $2.7 \pm 0.3$ \\
\hline 13 & $26 \pm 1$ & & $7 \pm 2$ & & & $4.4 \pm 0.1$ \\
\hline 32 & $41 \pm 5$ & & & $0.34 \pm 0.01$ & & $0.23 \pm 0.03$ \\
\hline 35 & $38 \pm 2$ & & & $3.8 \pm 0.3$ & & $6.5 \pm 0.6$ \\
\hline Galantamine & & $0.72 \pm 0.05$ & - & - & - & - \\
\hline Safinamide & - & - & $18 \pm 3$ & & & $0.031 \pm 0.001$ \\
\hline
\end{tabular}

${ }^{\mathrm{a}}$ Human recombinant enzymes. Values are mean $\pm \operatorname{SEM}(n=3)$.

Some positive results came out from MAOs inhibition tests, with indole derivative 32 acting as a strong inhibitor with submicromolar $\mathrm{IC}_{50} \mathrm{~s}$, although not isoform-selective. Another indole derivative, the quinoline arylhydrazone 35 , showed good inhibition of both isoforms, with a slight preference for MAO A. Isatin phenylhydrazone 5 displayed also good inhibitory potency against MAO A, with 7-fold selectivity over MAO B. N-Phenethylisatin 11, in turn, resulted as the best MAO B selective inhibitor, with $\mathrm{IC}_{50}$ in the low micromolar range. 


\subsection{Computational Studies}

We carried out computational ligand-based studies, namely pharmacophore modeling and atom-based 3D-QSAR study, on a pool of 93 already published compounds [15-17,19] (structures and related $A \beta$ antiaggregation data in Supplementary Materials) for better addressing the design of the new molecules sharing the indole/isatin scaffold. The ligand-based studies were aimed at deriving a comprehensive pharmacophore hypothesis to discern between 'actives', i.e., compounds achieving finite $\mathrm{IC}_{50}$ values under the threshold $100 \mu \mathrm{M}$ concentration, and 'inactives', i.e. compounds showing no activity or less than $50 \%$ inhibition at $100 \mu \mathrm{M}$. The pharmacophore was then complemented with a 3D-QSAR study limited to the 'active' molecules $\left(\mathrm{IC}_{50} \mathrm{~s}<100 \mu \mathrm{M}\right)$, the purpose being to predictively estimate the $A \beta$ inhibition potency of new indole/isatin derivatives and ultimately integrating and improving the physicochemical information content of the pharmacophore for a prospective design.

\subsubsection{Top-Scored Pharmacophore Model}

Five common features were mapped as relevant for the pharmacophore generation: two hydrogen bond acceptors (A), one hydrophobic region $(\mathrm{H})$ and two aromatic rings (R). More specifically, the features of AAHRR pharmacophore were mapped as follows: R12 and H11 refer to isatin, indoline or indandione cores, A2 and A1 refer to the carbonyl of isatin or indandione groups and nitrogen atom of hydrazone moiety, respectively, and R13 refers to phenyl or thiazole rings. Moreover, some excluded volumes were identified which locate sterically disallowed regions (Figure 2). This hypothesis matched 38 out of $54(70 \%)$ 'actives' and 39 out of $39(100 \%)$ 'inactives', thus having an overall accuracy equal to $82.80 \%$ (Figure 3).

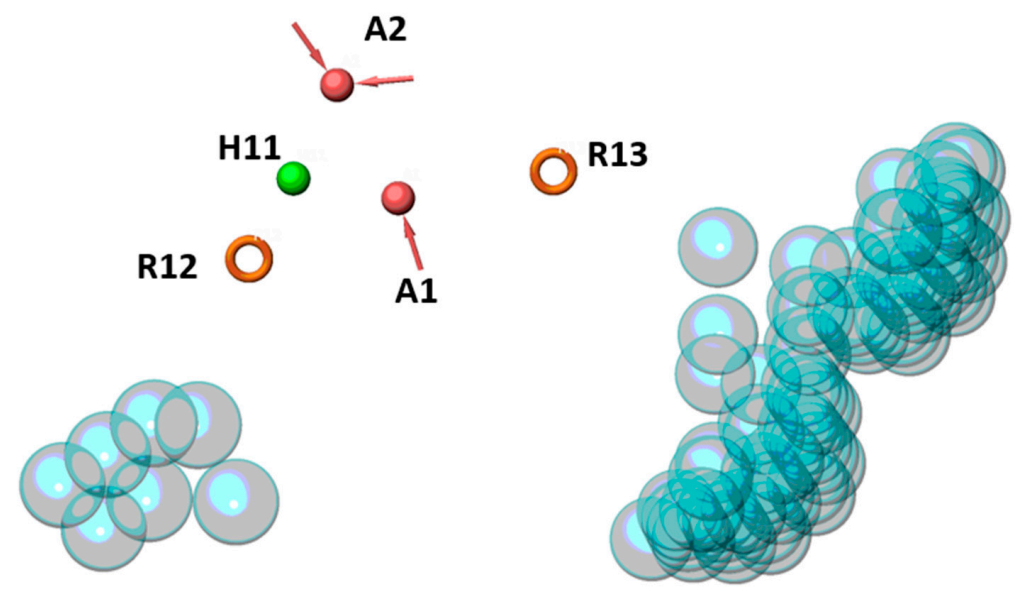

Figure 2. Pharmacophore hypothesis AAHRR. Orange circles, pink and green spheres indicate aromatic rings, hydrogen bonds acceptors and hydrophobic region features, respectively. Excluded volumes are depicted as translucent cyan spheres.
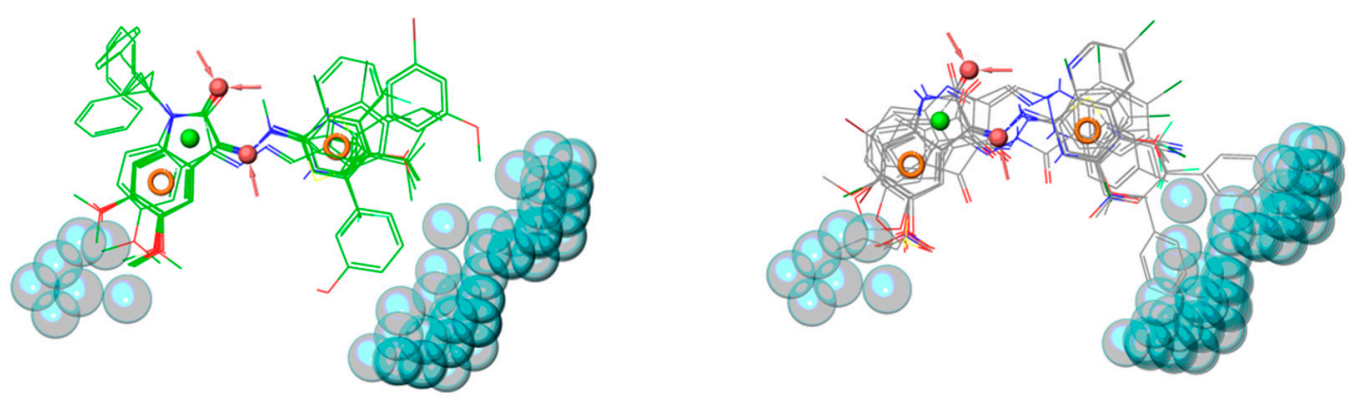

Figure 3. Overlay of actives (in green) and inactives (in gray) shown on the left-hand and right-hand side, respectively. 
This pharmacophore hypothesis was used to predict the 36 newly synthesized compounds (Tables 1-5) by setting a minimum number of at least four matched features. Satisfactorily, about $89 \%$ of new designed compounds (i.e., 32 out of 36) complied with the AAHRR pharmacophore hypothesis (Figure 4).

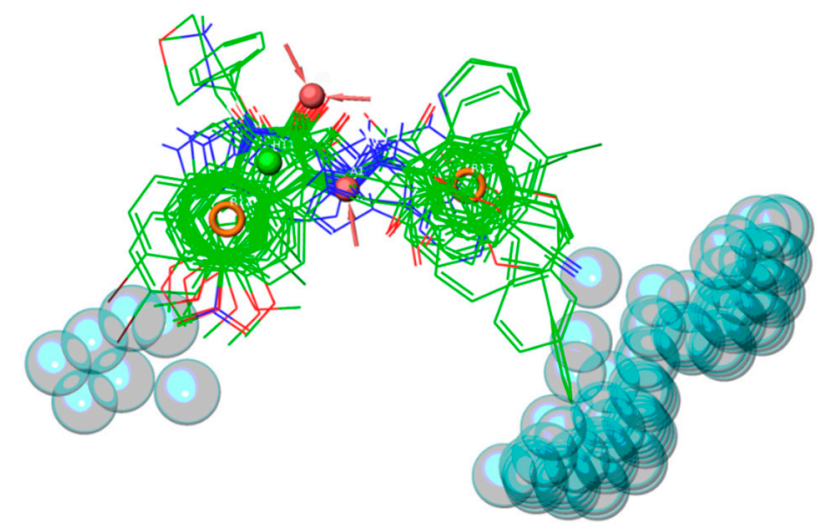

Figure 4. Overlay of the 36 new designed and prepared compounds, based on pharmacophore hypothesis AAHRR. Ligands are rendered as green wireframes.

\subsubsection{D-QSAR Model}

We derived an atom-based 3D-QSAR model by employing all the compounds achieving finite $\mathrm{IC}_{50}$ values below the maximum $100 \mu \mathrm{M}$ concentration tested. The training set was populated by 54 already reported compounds while the external set by 17 newly synthesized compounds. The first 3D-QSAR run which included all the 54 compounds into the training set did not yield any statistically meaningful model within the first five factors (i.e., PLS components). A careful check of the residuals [38,39] revealed a cluster of nine outliers (residuals $>2 s$ ): six bearing substituents (both polar and hydrophobic) at the para position of the phenyl ring (i.e., S29, S33, S49, S57 and S59 in Supplementary Materials) or at position 4 of the thiazole ring (S69) of the aryl-hydrazone moiety, and three lipophilic phenyl hydrazones of 3-oxo-3H-indole-2-carbaldehyde (S10, S14, and S15). Excluding relevant discrepancies arising from experimental procedures, as on the other hand confirmed by positive controls and re-determination of some representative 'old' compounds, the anomalous deviation from the model of these nine molecules may be likely due to the existence of a nonlinear correlation between the inhibition potency and the ligand hydrophobicity, as noticed by correlation with RP-HPLC parameter in our previous work [19]. In the PLS equation of the 3D-QSAR model there are no square neither cross terms which can account for nonlinear effects. Omitting from the PLS regression the nine outliers, the 3D-QSAR model, encompassing 45 molecules (83\%) of the whole training set, was able in predicting quite satisfactorily the $\mathrm{IC}_{50}$ values of $14(82 \%)$ external test set compounds $\left(\mathrm{r}^{2}\right.$ ext $\left.=0.695\right)$; three badly predicted compounds were the hydrazone derivatives 30,31 and 32 , sharing the $1 H$-indole core, a much less represented scaffold than $1 H$-indole-2,3-dione (i.e., isatin) in the training set.

The final 3D-QSAR model has the following features and statistics: four PLS factors; coefficient of determination $\mathrm{r}^{2}$ equal to 0.887 and a standard deviation value to 0.196 ; leave-one-out coefficient of determination $\mathrm{q}^{2}$ equal to 0.596 ; external coefficient of determination $\mathrm{r}^{2}$ ext equal to 0.695 and root mean square error (RMSE) value equal to 0.270 . Other statistical parameters could be additionally employed to support the prediction capability of the 3D-QSAR model [40]. We preferred validating the model with a true external set of compounds.

The grid-based 3D-QSAR model included the following molecular fields: hydrophobic/non-polar, electron-withdrawing and hydrogen bonds, whose relative contributions were equal to $74.3 \%, 17.7 \%$ and $7.5 \%$, respectively. The remaining $0.5 \%$ was due to a miscellaneous field [41]. All statistics related to the first four PLS components are summarized in Table 7. Moreover, the correlation between experimental and predicted $\mathrm{pIC}_{50}$ values for training and external test sets is shown in Figure 5. 
Table 7. Atom based 3D-QSAR statistics.

\begin{tabular}{cccccc}
\hline \# Factors & SD & $\mathbf{r}^{2}$ & $\mathbf{q}^{\mathbf{2}}$ & RMSE & $\mathbf{r}^{2}$ ext \\
\hline 1 & 0.383 & 0.533 & 0.320 & 0.290 & 0.651 \\
2 & 0.283 & 0.751 & 0.439 & 0.250 & 0.754 \\
3 & 0.231 & 0.838 & 0.563 & 0.260 & 0.720 \\
4 & 0.196 & 0.887 & 0.596 & 0.270 & 0.695 \\
\hline
\end{tabular}

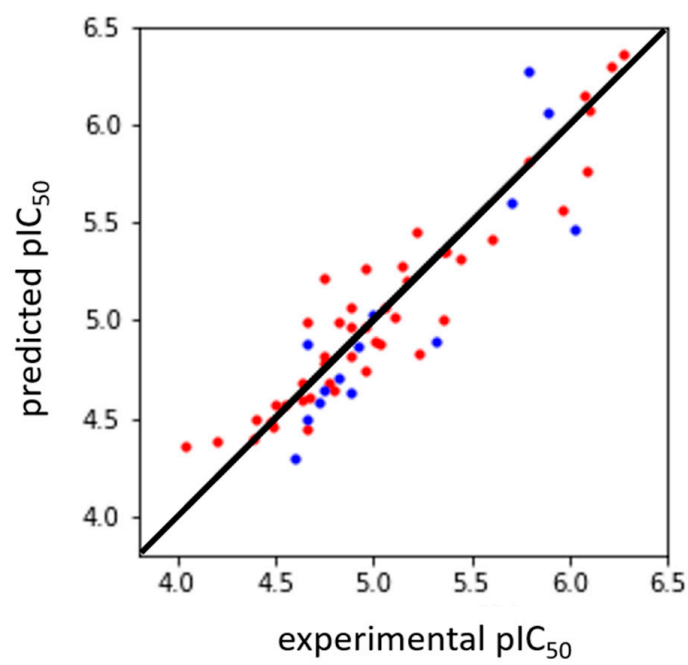

Figure 5. Scatter plot showing experimental vs. predicted $\mathrm{pIC}_{50}$ values for training $(n=45$, red solid circles) and external ( $n=14$, blue solid circles) sets, respectively. Bisector line is depicted in black. The $\mathrm{r}^{2}$ and $\mathrm{r}^{2}$ ext coefficient values were equal to 0.887 and 0.695 , respectively.

Contour maps of grid-based descriptors are reported in Figure 6 to spot positive or negative molecular regions for the activity of the compounds. Hydrophobic substituents at position 5 and 6 of isatin or indoline cores are detrimental for activity, much more than those at the ortho position of the phenyl ring. Furthermore, bulky substituents, such as iso-butyl or benzyloxy groups, at the para position of phenyl ring cause a drop of the activity and thus impact the excluded volumes of the pharmacophore model. Hydrogen bond donors, such as hydroxyl groups, can enhance the activity at the position 5 and 6 of the isatin core. The carbonyl groups of 3-indolinone or isatin are beneficial for activity, while electron-withdrawing substituents decrease the activity when branching the ortho position of the phenyl ring.
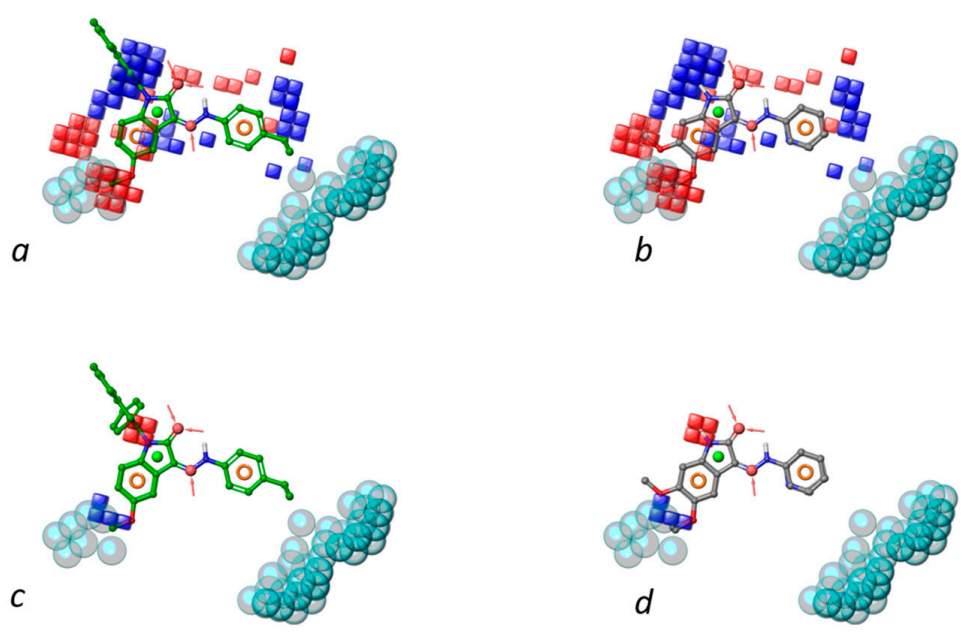

Figure 6. Cont. 

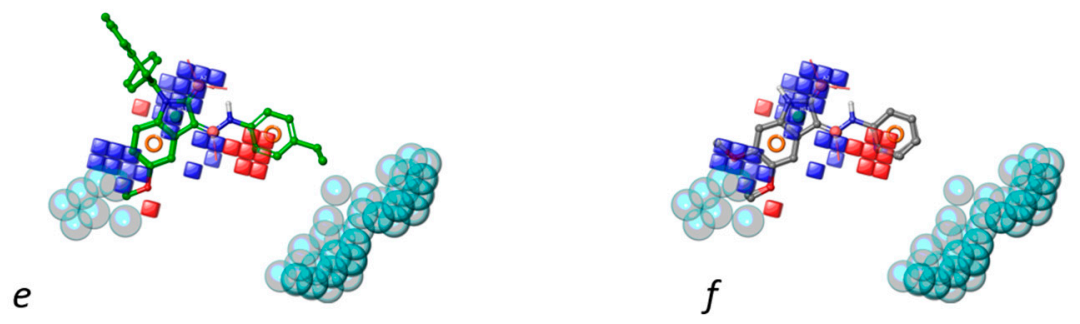

Figure 6. Contour maps rendered as blue and red cubes indicate positive and negative regions for activity. Specifically, panels $(\mathbf{a}, \mathbf{c}, \mathbf{e})$ show the most active ligands within hydrophobic, HBD and electron withdrawing region, respectively; panels $(\mathbf{b}, \mathbf{d}, \mathbf{f})$ show the most inactive ligands within hydrophobic, HBD and electron withdrawing regions, respectively. Pharmacophore features and excluded volumes are also reported.

\section{Materials and Methods}

\subsection{General Information}

Commercial reagents and solvents were purchased from Sigma-Aldrich (Milan, Italy). Melting points (mp) were determined by the capillary method on a Stuart SMP3 electrothermal apparatus (Bibby Scientific, Milan, Italy). IR spectra were recorded using potassium bromide disks on a Spectrum One FT-IR spectrophotometer (Perkin Elmer, Milan, Italy); only the most significant IR absorption bands are reported. ${ }^{1} \mathrm{H}-\mathrm{NMR}$ spectra were recorded in DMSO- $d_{6}, \mathrm{CDCl}_{3}$ or acetone- $d_{6}$ on a Mercury 300 or 500 spectrometer (Varian, Cernusco s. N., Italy). Chemical shifts are expressed in $\delta$ (ppm) and the coupling constants $J$ in Hz. The following abbreviations were used: s, singlet; d, doublet; $\mathrm{t}$, triplet; qn, quintuplet; ep, eptuplet; dd, double doublet; $\mathrm{td}$, triplet of doublets; m, multiplet; br s, broad singlet. Chromatographic separations were performed on silica gel 63-200 (Merck, Milan, Italy). ESI-MS was performed with an electrospray interface and an ion trap mass spectrometer (1100 Series LC/MSD Trap System, Agilent, Palo Alto, CA, USA). The sample was infused via a KD Scientific syringe pump at a rate of $10 \mathrm{~mL} / \mathrm{min}$. The pressure of the nebulizer gas was 15 psi. The drying gas was heated to $350^{\circ} \mathrm{C}$ at a flow of $5 \mathrm{~L} / \mathrm{min}$. Full-scan mass spectra were recorded in the mass/charge $(\mathrm{m} / \mathrm{z})$ range of 50-800 amu. For some representative compounds, HRMS experiments were performed with a dual electrospray interface (ESI) and a quadrupole time-of-flight mass spectrometer (Q-TOF, Agilent 6530 Series Accurate-Mass Quadrupole Time-of-Flight LC/MS, Agilent Technologies Italia S.p.A., Cernusco sul Naviglio, Italy). Compounds 2 [42], 4 [43], 5 [44], 10-12 and $\mathbf{1 4}$ [19], 30 [45], 33 [15], 44 [23] and 45 [24] have been prepared according to quoted references and their analytical data agreed with those reported in the literature.

\subsection{Chemistry}

\subsubsection{Synthesis of (Z)-3-Hydrazineylidene-5-nitroindolin-2-one (3)}

A mixture of 5-nitroisatin ( $1 \mathrm{mmol}, 1 \mathrm{eq})$ and hydrazine hydrate $55 \%$ (2.5 eq) in methanol $(1.5 \mathrm{~mL})$ was refluxed for $1 \mathrm{~h}$ and then cooled to room temperature, resulting in the precipitation of hydrazone that was filtered, dried and recrystallized from ethanol. Yield: $87 \% .{ }^{1} \mathrm{H}-\mathrm{NMR}$ (DMSO- $\left.d_{6}\right) \delta 6.99(\mathrm{~s}, 1 \mathrm{H}$, $\mathrm{H}-4), 8.10-8.06\left(\mathrm{~m}, 2 \mathrm{H}, \mathrm{H}-6\right.$ and H-7), $10.18\left(\mathrm{~d}, 1 \mathrm{H}, J_{\mathrm{v}}=12.5 \mathrm{~Hz}, \mathrm{~N}=\mathrm{NH}_{2}\right), 10.72\left(\mathrm{~d}, 1 \mathrm{H}, \mathrm{J}_{\mathrm{v}}=12.5 \mathrm{~Hz}\right.$, $\left.\mathrm{N}=\mathrm{NH}_{2}\right), \delta 11.30$ (br s, $1 \mathrm{H}, \mathrm{NH}$ indol.). MS (ESI), $m / z=204.9(100 \%)[\mathrm{M}-\mathrm{H}]^{-}$. IR (KBr): 3310, 1624, $1596,1331 \mathrm{~cm}^{-1}$. Mp $217-219{ }^{\circ} \mathrm{C}$.

\subsubsection{Synthesis of Aryl-hydrazineylidene indolinones 6-9}

Compounds 6-9 were synthesized by condensation of $N$-methylisatin or isatin with suitable arylhydrazine hydrochloride [19]. 
3-(2-(3-(Benzyloxy)phenyl)hydrazineylidene)indolin-2-one (6) Yield: $60 \% .{ }^{1} \mathrm{H}-\mathrm{NMR}(500 \mathrm{MHz}$, DMSO- $\left.d_{6}\right) \delta 5.12(\mathrm{~s}, 2 \mathrm{H}), 6.67(\mathrm{dd}, 1 \mathrm{H}, J=8.1,2.1 \mathrm{~Hz}), 6.89(\mathrm{~d}, 1 \mathrm{H}, J=7.8 \mathrm{~Hz}), 6.99-6.94(\mathrm{~m}$, $1 \mathrm{H}), 7.03(\mathrm{t}, 1 \mathrm{H}, J=7.6 \mathrm{~Hz}), 7.11(\mathrm{t}, 1 \mathrm{H}, J=2.1 \mathrm{~Hz}), 7.27-7.19(\mathrm{~m}, 2 \mathrm{H}), 7.31(\mathrm{t}, 1 \mathrm{H}, J=7.3 \mathrm{~Hz}), 7.38(\mathrm{t}, 2 \mathrm{H}$, $J=7.5 \mathrm{~Hz}), 7.46(\mathrm{~d}, 2 \mathrm{H}, J=7.3 \mathrm{~Hz}), 7.54(\mathrm{~d}, 1 \mathrm{H}, J=7.5 \mathrm{~Hz}), 10.99(\mathrm{~s}, 1 \mathrm{H}), 12.66(\mathrm{~s}, 1 \mathrm{H})$. HRMS (ESI) $\mathrm{m} / \mathrm{z}$ $[\mathrm{M}+\mathrm{Na}]^{+}$calcd for $\mathrm{C}_{21} \mathrm{H}_{17} \mathrm{~N}_{3} \mathrm{O}_{2} 366.1213$; found, 366.1195; [M - H] $]^{-}$calcd 342.1248; found, 342.1238 . IR (KBr): $3416,3162,1557,1207 \mathrm{~cm}^{-1}$. Mp $182-186^{\circ} \mathrm{C}$ from EtOH.

3-(2-(3-(Benzyloxy)phenyl)hydrazineylidene)-1-methylindolin-2-one (7) Yield: $55 \% .{ }^{1} \mathrm{H}-\mathrm{NMR}(500 \mathrm{MHz}$, DMSO- $\left.d_{6}\right) \delta 3.23(\mathrm{~s}, 3 \mathrm{H}), 5.12(\mathrm{~s}, 2 \mathrm{H}), 6.68(\mathrm{dd}, 1 \mathrm{H}, J=8.1,2.0 \mathrm{~Hz}), 6.98(\mathrm{dd}, 1 \mathrm{H}, J=8.0,1.3 \mathrm{~Hz}), 7.10(\mathrm{t}$, $2 \mathrm{H}, J=7.3 \mathrm{~Hz}), 7.13(\mathrm{t}, 1 \mathrm{H}, J=2.1 \mathrm{~Hz}), 7.25(\mathrm{t}, 1 \mathrm{H}, J=8.1 \mathrm{~Hz}), 7.31(\mathrm{dd}, 2 \mathrm{H}, J=11.6,4.1 \mathrm{~Hz}), 7.38(\mathrm{t}, 2 \mathrm{H}$, $J=7.5 \mathrm{~Hz}), 7.46(\mathrm{~d}, 2 \mathrm{H}, J=7.4 \mathrm{~Hz}), 7.61-7.56(\mathrm{~m}, 1 \mathrm{H}), 12.60(\mathrm{~s}, 1 \mathrm{H})$. HRMS (ESI) $\mathrm{m} / z[\mathrm{M}+\mathrm{Na}]^{+}$calcd for $\mathrm{C}_{22} \mathrm{H}_{19} \mathrm{~N}_{3} \mathrm{O}_{2}$ 380.1369; found, 380.1374; [M - H] ${ }^{-}$calcd 356.1405; found, 356.1391. IR (KBr): 3418, $1676,1567 \mathrm{~cm}^{-1}$. Mp $134-137^{\circ} \mathrm{C}$ from EtOH.

3-(2-(4-(Benzyloxy)phenyl)hydrazineylidene)indolin-2-one (8) Yield: $54 \% .{ }^{1} \mathrm{H}-\mathrm{NMR}(500 \mathrm{MHz}$, DMSO- $\left.d_{6}\right) \delta 5.06(\mathrm{~d}, 2 \mathrm{H}, J=5.7 \mathrm{~Hz}), 6.89(\mathrm{~d}, 1 \mathrm{H}, J=7.8 \mathrm{~Hz}), 7.02(\mathrm{dd}, 3 \mathrm{H}, J=12.5,5.8 \mathrm{~Hz})$, $7.19(\mathrm{td}, 1 \mathrm{H}, J=7.7,1.0 \mathrm{~Hz}), 7.31(\mathrm{t}, 1 \mathrm{H}, J=7.3 \mathrm{~Hz}), 7.39-7.33(\mathrm{~m}, 4 \mathrm{H}), 7.43(\mathrm{~d}, 2 \mathrm{H}, J=7.3 \mathrm{~Hz}), 7.50(\mathrm{~d}$, $1 \mathrm{H}, J=7.3 \mathrm{~Hz}), 10.93(\mathrm{~s}, 1 \mathrm{H}), 12.73(\mathrm{~s}, 1 \mathrm{H})$. HRMS (ESI) $\mathrm{m} / z[\mathrm{M}+\mathrm{Na}]^{+}$calcd for $\mathrm{C}_{21} \mathrm{H}_{17} \mathrm{~N}_{3} \mathrm{O}_{2} 366.1213$; found, 366.1206; [M - H] $]^{-}$calcd 342.1248; found, 342.1239. IR (KBr): 3418, 1680, 1552, 1228, $1174 \mathrm{~cm}^{-1}$. $\mathrm{Mp} 201-206^{\circ} \mathrm{C}$ from $\mathrm{EtOH}$.

3-(2-(4-(Benzyloxy)phenyl)hydrazineylidene)-1-methylindolin-2-one (9) Yield: 50\%. ${ }^{1} \mathrm{H}-\mathrm{NMR}(500 \mathrm{MHz}$, DMSO- $\left.d_{6}\right) \delta 3.23(\mathrm{~s}, 3 \mathrm{H}), 5.07(\mathrm{~s}, 2 \mathrm{H}), 7.02(\mathrm{~d}, 2 \mathrm{H}, J=9.0 \mathrm{~Hz}), 7.08(\mathrm{t}, 2 \mathrm{H}, J=7.2 \mathrm{~Hz}), 7.33-7.25(\mathrm{~m}, 2 \mathrm{H})$, $7.37(\mathrm{dd}, 4 \mathrm{H}, J=8.2,5.3 \mathrm{~Hz}), 7.43(\mathrm{~d}, 2 \mathrm{H}, J=7.2 \mathrm{~Hz}), 7.56-7.50(\mathrm{~m}, 1 \mathrm{H}), 12.67(\mathrm{~s}, 1 \mathrm{H})$. HRMS (ESI) $\mathrm{m} / \mathrm{z}$ $[\mathrm{M}+\mathrm{Na}]^{+}$calcd for $\mathrm{C}_{22} \mathrm{H}_{19} \mathrm{~N}_{3} \mathrm{O}_{2}$ 380.1369; found, 380.1373; [M - H] $]^{-}$calcd 356.1405; found, 356.1390 . IR (KBr): $3435,1667,1555,1218 \mathrm{~cm}^{-1}$. Mp $126-128^{\circ} \mathrm{C}$ from EtOH.

\subsubsection{Alkylation of 5-Methoxyindoline-2,3-diones $\mathbf{1 3}$ and $\mathbf{1 5}$}

\section{5-Methoxy-1-(morpholinomethyl)indoline-2,3-dione (13)}

To a solution of formaldehyde ( $37 \%$ in $\mathrm{H}_{2} \mathrm{O}, 4$ eq) and morpholine (2 eq) in ethanol (10 mL) was added $5 \mathrm{~mL}$ of ethanoic solution of 5-methoxyisatin ( $1 \mathrm{mmol}, 1 \mathrm{eq})$. The mixture was refluxed for 2 days and after TLC control, the solvent was evaporated, and the residue crystalized. Yield: $61 \%$. ${ }^{1} \mathrm{H}-\mathrm{NMR}\left(\mathrm{CDCl}_{3}\right) \delta 2.61\left(\mathrm{t}, 4 \mathrm{H}, J=4.7 \mathrm{~Hz}, \mathrm{CH}_{2} \mathrm{CH}_{2}\right.$ morpholine), $3.69\left(\mathrm{t}, 4 \mathrm{H}, J=4.7 \mathrm{~Hz}, \mathrm{CH}_{2} \mathrm{CH}_{2}\right.$ morpholine), $3.81\left(\mathrm{~s}, 3 \mathrm{H}, \mathrm{OCH}_{3}\right), 4.41\left(\mathrm{~s}, 2 \mathrm{H}, \mathrm{N}-\mathrm{CH}_{2}\right), 7.02(\mathrm{~d}, 1 \mathrm{H}, \mathrm{Jo}=9.1 \mathrm{~Hz}, \mathrm{H}-7), 7.14-7.18(\mathrm{~m}, 2 \mathrm{H}$, H-4 and H-6). MS (ESI), $m / z=299.0(100 \%)[\mathrm{M}+\mathrm{Na}]^{+}$. IR (KBr): 2847, 2833, 1738, 1490, $1313 \mathrm{~cm}^{-1}$. $\mathrm{Mp} 107-110^{\circ} \mathrm{C}$ from $\mathrm{EtOH}$.

\section{1-(2-(Dimethylamino)ethyl)-5-methoxyindoline-2,3-dione (15)}

A solution in DMF (11 mL) of 5-methoxyisatine ( $2.8 \mathrm{mmol}, 1 \mathrm{eq}), 2$-chloro $\mathrm{N}, \mathrm{N}$-dimethylethylamine hydrochloride (1.3 eq) and potassium carbonate (3 eq) was stirred overnight at room temperature. The mixture was filtered, and the solution was evaporated to afford a red oil that was purified by column chromatography. Yield: 75\%. ${ }^{1} \mathrm{H}-\mathrm{NMR}\left(\mathrm{CDCl}_{3}\right) \delta 2.29\left(\mathrm{~s}, 6 \mathrm{H}, \mathrm{N}\left(\mathrm{CH}_{3}\right)_{2}\right), 2.57(\mathrm{t}, 2 \mathrm{H}, J v=6.9 \mathrm{~Hz}$, $\left.\mathrm{CH}_{2}\right), 3.83-3.77\left(\mathrm{~m}, 5 \mathrm{H}, \mathrm{CH}_{2}\right.$ and $\left.\mathrm{OCH}_{3}\right), 6.87-6.83(\mathrm{~m}, 1 \mathrm{H}), 7.16-7.10(\mathrm{~m}, 2 \mathrm{H})$. MS $(\mathrm{ESI}), \mathrm{m} / \mathrm{z}=271.10$ $(100 \%)[\mathrm{M}+\mathrm{Na}]^{+}$. IR (KBr): 2943, 1731, 1484, $1163 \mathrm{~cm}^{-1}$. Mp 95-97 ${ }^{\circ} \mathrm{C}$ from $\mathrm{CHCl}_{3} / \mathrm{MeOH} 90: 10(v / v)$.

\subsubsection{1-(2-(Dimethylamino)ethyl)-3-(2-(4-isopropylphenyl)hydrazineylidene)-5-methoxyindolin-2-one (18)}

Compound 18 was synthesized by condensation of 15 with 4-isopropylphenylhydrazine hydrochloride as previously described [19]. Yield: $35 \% .{ }^{1} \mathrm{H}-\mathrm{NMR}\left(\mathrm{DMSO}-d_{6}\right) \delta 1.14(\mathrm{~d}, 6 \mathrm{H}, J v=7.1 \mathrm{~Hz}$, $\left.\mathrm{CH}\left(\mathrm{CH}_{3}\right)_{2}\right), 2.75-2.91\left(\mathrm{~m}, 7 \mathrm{H}, \underline{\mathrm{CH}}\left(\mathrm{CH}_{3}\right)_{2}, \mathrm{~N}\left(\mathrm{CH}_{3}\right)_{2}\right), 3.30-3.45\left(\mathrm{~m}, 2 \mathrm{H}, \mathrm{NCH}_{2} \mathrm{CH}_{2} \mathrm{~N}_{\left.\left(\mathrm{CH}_{3}\right)_{2}\right)} 3.79\right.$ (s, $\left.3 \mathrm{H}, \overline{\mathrm{OCH}_{3}}\right), 4.17\left(\mathrm{t}, 2 \mathrm{H}, J v=6.0 \mathrm{~Hz}, \mathrm{NCH}_{2} \mathrm{CH}_{2} \mathrm{~N}\left(\mathrm{CH}_{3}\right)_{2}\right), 6.90(\mathrm{dd}, 1 \mathrm{H}, J o=8.3, J m=2.3 \mathrm{~Hz}, \mathrm{H}-6)$, 7.12-7.26 (m, 4H, H-4, H-7, H-3' and H-5'), $7.39\left(\mathrm{~d}, 2 \mathrm{H}, J=8.5 \mathrm{~Hz}, \mathrm{H}-2^{\prime}\right.$ and $\left.\mathrm{H}-6^{\prime}\right), 12.60(\mathrm{~s}, 1 \mathrm{H}, \mathrm{NNH})$. 
MS (ESI), $m / z=379.2(100 \%)[\mathrm{M}-\mathrm{H}]^{-}, 403.2(100 \%)[\mathrm{M}+\mathrm{Na}]^{+} . \mathrm{IR}(\mathrm{KBr}): 2959,1670,1521,1485 \mathrm{~cm}^{-1}$. Mp 222-224 ${ }^{\circ} \mathrm{C}$ from $\mathrm{EtOH} / \mathrm{H}_{2} \mathrm{O}$.

\subsubsection{Synthesis of 5-Hydroxy-isopropylphenyl-hydrazineylidene indolinones 19 and 20}

The debenzylation with $\mathrm{BBr}_{3}$ in dichloromethane at $-70{ }^{\circ} \mathrm{C}$ [16] of compounds $\mathbf{1 6}$ and $\mathbf{1 7}$ [19] gave the 19 and 20, respectively.

1-Benzyl-5-hydroxy-3-(2-(4-isopropylphenyl)hydrazineylidene)indolin-2-one (19). Yield: 20\%. ${ }^{1} \mathrm{H}-\mathrm{NMR}$ $\left(\mathrm{DMSO}-d_{6}\right) \delta 1.19\left(\mathrm{~d}, 6 \mathrm{H}, \mathrm{Jv}=7.0 \mathrm{~Hz}, \mathrm{CH}\left(\mathrm{CH}_{3}\right)_{2}\right), 2.86\left(\mathrm{ept}, 1 \mathrm{H}, \mathrm{Jv}=7.0 \mathrm{~Hz}, \underline{\mathrm{CH}}\left(\mathrm{CH}_{3}\right)_{2}\right), 4.94(\mathrm{~s}, 2 \mathrm{H}$, $\left.\mathrm{CH}_{2}-\mathrm{Ph}\right), 6.62(\mathrm{dd}, 1 \mathrm{H}, J o=8.4, J m=2.4 \mathrm{~Hz}, \mathrm{H}-6), 6.82(\mathrm{~d}, 1 \mathrm{H}, J o=8.4 \mathrm{~Hz}, \mathrm{H}-7), 6.98(\mathrm{~d}, 1 \mathrm{H}, J m=2.4 \mathrm{~Hz}$, H-4), $7.24\left(\mathrm{~d}, 2 \mathrm{H}, J=8.8 \mathrm{~Hz}, \mathrm{H}-3^{\prime}\right.$ and H-5'), 7.27-7.36 (m, 7H, H-2', H-6, H-2 ${ }^{\prime \prime}, \mathrm{H}-3^{\prime \prime}, \mathrm{H}-4^{\prime \prime}, \mathrm{H}-5^{\prime \prime}$ and $\left.\mathrm{H}-6^{\prime \prime}\right), 9.21$ (s, 1H, OH), 12.71 (s, 1H, NNH). MS (ESI), $m / z=383.9$ (100\%) [M - H] $]^{-}$. IR (KBr): 3991, $3032,1655,1519,1164 \mathrm{~cm}^{-1}$. Mp 188-190 ${ }^{\circ} \mathrm{C}$ from hexane/ethyl acetate 70:30 (v/v).

1-Cyclopropyl-5-hydroxy-3-(2-(4-isopropylphenyl)hydrazono)indolin-2-one (20). Yield: $20 \% .{ }^{1} \mathrm{H}-\mathrm{NMR}$

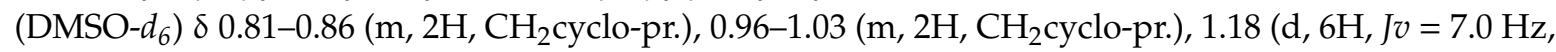
$\left.\mathrm{CH}\left(\mathrm{CH}_{3}\right)_{2}\right), 2.73$ (qn, $1 \mathrm{H}, J v=3.7 \mathrm{~Hz}, \mathrm{CHcyclopr}$ ), $2.85\left(\mathrm{ep}, 1 \mathrm{H}, \mathrm{Jv}=7.0 \mathrm{~Hz}, \underline{\mathrm{CH}}\left(\mathrm{CH}_{3}\right)_{2}\right), 6.72$ (dd, $1 \mathrm{H}, J o=8.4, J m=2.6 \mathrm{~Hz}, \mathrm{H}-6), 6.94(\mathrm{~d}, 1 \mathrm{H}, J m=2.4 \mathrm{~Hz}, \mathrm{H}-4), 6.99(\mathrm{~d}, 1 \mathrm{H}, J o=8.4 \mathrm{~Hz}, \mathrm{H}-7), 7.22(\mathrm{~d}$, $2 \mathrm{H}, J=8.6 \mathrm{~Hz}, \mathrm{H}-3^{\prime}$ and $\left.\mathrm{H}-5^{\prime}\right), 7.31\left(\mathrm{~d}, 2 \mathrm{H}, J=8.4 \mathrm{~Hz}, \mathrm{H}-2^{\prime}\right.$ and $\left.\mathrm{H}-6^{\prime}\right), 9.21(\mathrm{~s}, 1 \mathrm{H}, \mathrm{OH}), 12.74(\mathrm{~s}, 1 \mathrm{H}$, $\mathrm{NNH})$. MS (ESI), $m / z=333.9$ (100\%) [M - H] $]^{-}$. IR (KBr): 3305, 2920, 1656, 1559, 1390, 1190, $1138 \mathrm{~cm}^{-1}$. Mp 222-224 ${ }^{\circ} \mathrm{C}$ from hexane/ethyl acetate 75:25 (v/v).

\subsubsection{Synthesis of 3-Arylhydrazono-indolin-2-ones 23-25}

Compounds 23-25 were prepared from azo coupling of aryldiazonium salts 22a-c with indolin-2-one 21, previously prepared [20]. Aryldiazonium salts were synthesized starting from corresponding amines as described in a previous paper [19].

3-(2-(Naphthalen-1-yl)hydrazono)indolin-2-one (23). Yield: 20\%. ${ }^{1} \mathrm{H}-\mathrm{NMR}\left(\mathrm{DMSO}-\mathrm{d}_{6}\right) \delta 6.97(\mathrm{~d}, 1 \mathrm{H}$, $J o=7.7 \mathrm{~Hz}, \mathrm{H}-7), 7.09$ (t, $1 \mathrm{H}, J o=7.7 \mathrm{~Hz}, J o=7.3 \mathrm{~Hz}, \mathrm{H}-5), 7.28(\mathrm{t}, 1 \mathrm{H}, J o=7.7 \mathrm{~Hz}, \mathrm{H}-6), 7.54-7.69$ (m, $5 \mathrm{H}, \mathrm{H}-3^{\prime}, \mathrm{H}^{-} 4^{\prime \prime}, \mathrm{H}-5^{\prime}, \mathrm{H}-6^{\prime}$ and H-7'), $7.82(\mathrm{~d}, 1 \mathrm{H}, \mathrm{Jo}=7.3 \mathrm{~Hz}, \mathrm{H}-4), 7.89\left(\mathrm{~d}, 1 \mathrm{H}, J o=8.4 \mathrm{~Hz}, \mathrm{H}-2^{\prime}\right), 7.98$ $\left(\mathrm{d}, 1 \mathrm{H}, J o=8.1 \mathrm{~Hz}, \mathrm{H}-8^{\prime}\right), 11.23(\mathrm{~s}, 1 \mathrm{H}, \mathrm{NH}), 13.79(\mathrm{~s}, 1 \mathrm{H}, \mathrm{NNH})$. MS (ESI), $m / z=285.8(100 \%)[\mathrm{M}-\mathrm{H}]^{-}$. IR (KBr): $3413,3121,3049,1675,1561,1196 \mathrm{~cm}^{-1}$. Mp 225-230 ${ }^{\circ} \mathrm{C}$ from hexane/ethyl acetate 80:20 (v/v).

3-(2-(Naphthalen-2-yl)hydrazono)indolin-2-one (24). Yield: 30\%. ${ }^{1} \mathrm{H}-\mathrm{NMR}\left(\mathrm{DMSO}-\mathrm{d}_{6}\right) \delta 6.92(\mathrm{~d}, 1 \mathrm{H}$, $J o=7.7 \mathrm{~Hz}, \mathrm{H}-7), 7.06(\mathrm{t}, 1 \mathrm{H}, J o=7.7$ and $7.3 \mathrm{~Hz}, \mathrm{H}-5), 7.25(\mathrm{td}, 1 \mathrm{H}, J m=1.1 \mathrm{~Hz}, J o=7.7 \mathrm{~Hz}, \mathrm{H}-6), 7.36(\mathrm{t}$, $1 \mathrm{H}, J o=8.1$ and $\left.7.0 \mathrm{~Hz}, \mathrm{H}-6^{\prime}\right), 7.41\left(\mathrm{t}, 1 \mathrm{H}, J o=8.1\right.$ and $\left.7.0 \mathrm{~Hz}, \mathrm{H}_{-} 7^{\prime}\right), 7.61(\mathrm{~d}, 1 \mathrm{H}, J o=7.3 \mathrm{~Hz}, \mathrm{H}-4), 7.71$ $\left(\mathrm{dd}, 1 \mathrm{H}, J m=1.8 \mathrm{~Hz}, J o=8.8 \mathrm{~Hz}, \mathrm{H}-3^{\prime}\right), 7.83-7.86\left(\mathrm{~m}, 3 \mathrm{H}, \mathrm{H}-\mathrm{1}^{\prime}, \mathrm{H}-5^{\prime}\right.$ and $\left.\mathrm{H}-8^{\prime}\right), 7.93(\mathrm{~d}, 1 \mathrm{H}, J o=8.8 \mathrm{~Hz}$, H-4' $), 11.05$ (s, 1H, NH), 12.95 (s, 1H, NNH). MS (ESI), $m / z=285.8(100 \%)[\mathrm{M}-\mathrm{H}]^{-}$. IR (KBr): 3159, $1676,1555,1223,1190 \mathrm{~cm}^{-1}$. Mp $245-248^{\circ} \mathrm{C}$ from hexane/ethyl acetate 70:30 (v/v).

3-(2-(Quinolin-8-yl)hydrazineylidene)indolin-2-one (25). Yield: 21\%. ${ }^{1} \mathrm{H}-\mathrm{NMR}$ (DMSO-d 6 ) $86.92(\mathrm{~d}$, $1 \mathrm{H}, J o=7.5 \mathrm{~Hz}, \mathrm{H}-7), 7.06(\mathrm{t}, 1 \mathrm{H}, J o=7.7 \mathrm{~Hz}, \mathrm{H}-5), 7.26(\mathrm{t}, 1 \mathrm{H}, J o=7.7 \mathrm{~Hz}, \mathrm{H}-6), 7.58-7.67\left(\mathrm{~m}, 4 \mathrm{H}, \mathrm{H}-3^{\prime}\right.$, $\mathrm{H}-4^{\prime}, \mathrm{H}-6^{\prime}$ and $\left.\mathrm{H}-4\right), 7.93\left(\mathrm{dd}, 1 \mathrm{H}, J o=7.0, J m=2.2 \mathrm{~Hz}, \mathrm{H}-5^{\prime}\right), 8.39\left(\mathrm{dd}, 1 \mathrm{H}, J o=8.4, J m=1.6 \mathrm{~Hz}, \mathrm{H}-2^{\prime}\right)$, 8.91-8.93 (m, 1H, H-7'), $11.07(\mathrm{~s}, 1 \mathrm{H}, \mathrm{NH}), 13.91(\mathrm{~s}, 1 \mathrm{H}, \mathrm{NNH})$. MS (ESI), $m / z=311.0(100 \%)[\mathrm{M}+\mathrm{Na}]^{+}$. IR (KBr): $3447,3152,1682,1523,1198 \mathrm{~cm}^{-1}$. $\mathrm{Mp}>250{ }^{\circ} \mathrm{C}$ dec. from $\mathrm{CH}_{2} \mathrm{Cl}_{2} / \mathrm{MeOH} 96: 4(v / v)$.

\subsubsection{N'-(5-Methoxy-2-oxoindolin-3-ylidene)benzhydrazide (26)}

The compound was synthesized by condensation of 5-methoxyisatin and benzhydrazide as previously described [19]. Yield: 37\%. ${ }^{1} \mathrm{H}-\mathrm{NMR}\left(\mathrm{DMSO}_{6} \mathrm{~d}_{6}\right) \delta 3.77\left(\mathrm{~s}, 3 \mathrm{H}, 5-\mathrm{OCH}_{3}\right), 6.87(\mathrm{~d}, 1 \mathrm{H}$, $J=8.6 \mathrm{~Hz}, \mathrm{H}-7), 6.96(\mathrm{dd}, 1 \mathrm{H}, J o=8.6, J m=2.6 \mathrm{~Hz}, \mathrm{H}-6), 7.13(\mathrm{~d}, 1 \mathrm{H}, J m=2.6 \mathrm{~Hz}, \mathrm{H}-4), 7.59(\mathrm{dd}, 2 \mathrm{H}$, $J o=8.4, J m=1.5 \mathrm{~Hz}, \mathrm{H}-5^{\prime}$ and $\left.\mathrm{H}^{\prime}\right), 7.63-7.61\left(\mathrm{~m}, 1 \mathrm{H}, \mathrm{H}-4^{\prime}\right), 7.88\left(\mathrm{dd}, 2 \mathrm{H}, J o=8.4, J m=1.5 \mathrm{~Hz}, \mathrm{H}-2^{\prime}\right.$ and $\left.\mathrm{H}-6^{\prime}\right), 11.20$ (br s, 1H, NH), 13.90 (br s, 1H, NNHCO). ESI-MS $m / z=318.0(100 \%)\left[\mathrm{M}+\mathrm{Na}^{+}, 293.8\right.$ (100\%) $[\mathrm{M}-\mathrm{H}]^{-}$. IR (KBr): $3254,1704,1691,1675,1486 \mathrm{~cm}^{-1} . \mathrm{Mp}>250{ }^{\circ} \mathrm{C}$ from $\mathrm{CH}_{2} \mathrm{Cl}_{2} / \mathrm{MeOH}$ $96: 4(v / v)$. 


\subsubsection{2-(4-Hydroxybenzylidene)indolin-3-one (27)}

Compound 27 was prepared following literature procedures [46]. Yield: $25 \% .{ }^{1} \mathrm{H}-\mathrm{NMR}\left(\mathrm{DMSO}-d_{6}\right)$ $\delta 6.60(\mathrm{~s}, 1 \mathrm{H},=\mathrm{CH}), 6.85\left(\mathrm{~d}, 2 \mathrm{H}, J o=8.7 \mathrm{~Hz}, \mathrm{H}-3^{\prime}\right.$ and H-5'), $6.87(\mathrm{t}, 1 \mathrm{H}, J o=7.6 \mathrm{~Hz}, \mathrm{H}-5), 7.11(\mathrm{~d}, 1 \mathrm{H}$, $J o=8.3 \mathrm{~Hz}, \mathrm{H}-7), 7.48(\mathrm{td}, 1 \mathrm{H}, J o=8.8, J m=1.1 \mathrm{~Hz}, \mathrm{H}-6), 7.54(\mathrm{~d}, 1 \mathrm{H}, J o=7.6 \mathrm{~Hz}, \mathrm{H}-4), 7.68(\mathrm{~d}, 2 \mathrm{H}$, Jo $=8.7 \mathrm{~Hz}, \mathrm{H}-2^{\prime}$ and H-6'), 9.54 (s, 1H, NH), 9.98 (br s, 1H, OH). MS (ESI), m/z = $235.9(100 \%)[\mathrm{M}-\mathrm{H}]^{-}$. IR (KBr): $3311,1672,1591,1509,1488,1243 \mathrm{~cm}^{-1}$. Mp $>250{ }^{\circ} \mathrm{C}$.

\subsubsection{Synthesis of Hydrazonomethyl-indoles 28, 29, 31, 32, 34-36}

The synthesis of hydrazonomethyl-indoles was performed as previously described [19] by the condensation of corresponding indole carbaldehyde and arylhydrazine. Then the desired compounds were purified by crystallization or column chromatography.

3-((2-(4-Isopropylphenyl)hydrazono)methyl)-1H-indole (28). Yield: 30\%. ${ }^{1} \mathrm{H}-\mathrm{NMR}\left(\mathrm{DMSO}-\mathrm{d}_{6}\right) \delta 1.16$ $\left(\mathrm{d}, 6 \mathrm{H}, J=7.0 \mathrm{~Hz}, \mathrm{CH}\left(\mathrm{CH}_{3}\right)_{2}\right), 2.80\left(\mathrm{ep}, 1 \mathrm{H}, J=7.0 \mathrm{~Hz}, \underline{\mathrm{CH}}\left(\mathrm{CH}_{3}\right)_{2}\right), 6.96-7.40\left(\mathrm{~m}, 6 \mathrm{H}, \mathrm{H}-6, \mathrm{H}-7, \mathrm{H}-2^{\prime}\right.$,

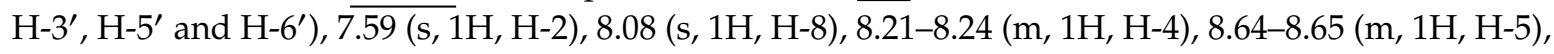
11.31 (s, 1H, NH), 12.79 (s, 1H, NNH). MS (ESI), m/z = $275.9(100 \%)[\mathrm{M}-\mathrm{H}]^{-}$. IR (KBr): 3436, 2841, $1644,1489,1428,1223,1146,751 \mathrm{~cm}^{-1}$. Mp 200-205 ${ }^{\circ} \mathrm{C}$ from EtOH.

4-(2-((5-Methoxy-1H-indol-3-yl)methylene)hydrazineyl)benzonitrile (29). Yield: $30 \% .{ }^{1} \mathrm{H}-\mathrm{NMR}$ $\left(\mathrm{DMSO}_{6}\right) \delta 3.82\left(\mathrm{~s}, 3 \mathrm{H}, \mathrm{OCH}_{3}\right), 6.84(\mathrm{dd}, 1 \mathrm{H}, \mathrm{Jm}=2.6, J o=8.8 \mathrm{~Hz}, \mathrm{H}-6), 7.06\left(\mathrm{~d}, 2 \mathrm{H}, J=8.6 \mathrm{~Hz}, \mathrm{H}-2^{\prime}\right.$ and $\left.\mathrm{H}-6^{\prime}\right), 7.31(\mathrm{~d}, 1 \mathrm{H}, J o=8.8 \mathrm{~Hz}, \mathrm{H}-7), 7.59\left(\mathrm{~d}, 2 \mathrm{H}, \mathrm{J}=8.6 \mathrm{~Hz}, \mathrm{H}-3^{\prime}\right.$ and H-5'), $7.69(\mathrm{~s}, 1 \mathrm{H}, \mathrm{H}-2), 7.71(\mathrm{~d}$, $1 \mathrm{H}, \mathrm{Jm}=2.6 \mathrm{~Hz}, \mathrm{H}-4), 8.17(\mathrm{~s}, 1 \mathrm{H}, \mathrm{CH}=\mathrm{N}), 10.55(\mathrm{~s}, 1 \mathrm{H}, \mathrm{NH}), 11.33(\mathrm{~s}, 1 \mathrm{H}, \mathrm{NNH}) . \mathrm{MS}(\mathrm{ESI}), m / z=288.8$ $(100 \%)[\mathrm{M}-\mathrm{H}]^{-}$. IR (KBr): 3290, 2220, 1603, 1532, 1290, $1258 \mathrm{~cm}^{-1}$. Mp 227-229 ${ }^{\circ} \mathrm{C}$ from EtOH.

3-((2-(3-Chlorophenyl)hydrazineylidene)methyl)-5-methoxy-1H-indole (31). Yield: 30\%. ${ }^{1} \mathrm{H}-\mathrm{NMR}$ $\left(\mathrm{DMSO}_{-} \mathrm{d}_{6}\right) \delta 3.84\left(\mathrm{~s}, 3 \mathrm{H}, \mathrm{OCH}_{3}\right), 6.66\left(\mathrm{dd}, 1 \mathrm{H}, \mathrm{Jm}=2.1, \mathrm{Jo}=8.3 \mathrm{~Hz}, \mathrm{H}-4^{\prime}\right), 6.82(\mathrm{dd}, 1 \mathrm{H}, J m=2.6$, $J o=8.8 \mathrm{~Hz}, \mathrm{H}-6), 6.86\left(\mathrm{dd}, 1 \mathrm{H}, J m=2.1, J o=8.3 \mathrm{~Hz}, \mathrm{H}-6^{\prime}\right), 7.11\left(\mathrm{t}, 1 \mathrm{H}, J m=2.1 \mathrm{~Hz}, \mathrm{H}-2^{\prime}\right), 7.18(\mathrm{t}, 1 \mathrm{H}$, $\left.J o=8.3, \mathrm{H}-5^{\prime}\right), 7.30(\mathrm{~d}, 1 \mathrm{H}, J o=8.8 \mathrm{~Hz}, \mathrm{H}-7), 7.61($ br s, $1 \mathrm{H}, \mathrm{H}-2), 7.75(\mathrm{~d}, 1 \mathrm{H}, J m=2.6 \mathrm{~Hz}, \mathrm{H}-4), 8.09$ (s, $1 \mathrm{H}, \mathrm{CH}=\mathrm{N}), 10.08$ (s, 1H, NH), 11.23 (s, 1H, NNH). MS (ESI), m/z= $297.8(100 \%)[\mathrm{M}-\mathrm{H}]^{-}, 299.8(33 \%)$ $[\mathrm{M}-\mathrm{H}]^{-}+2$. IR (KBr): 3430, 2922, 1614, 1596, 1484, $1210 \mathrm{~cm}^{-1}$. Mp 83-85 ${ }^{\circ} \mathrm{C}$ from ethyl acetate/hexane 50:50 (v/v).

3-((2-(4-Chlorophenyl)hydrazono)methyl)-1H-indole (32). Yield: 30\%. ${ }^{1} \mathrm{H}-\mathrm{NMR}$ (acetone- $\left.\mathrm{d}_{6}\right) \delta 7.15(\mathrm{~d}$, $2 \mathrm{H}, J=9.1 \mathrm{~Hz}, \mathrm{H}-2^{\prime}$ and H-6' $), 7.23\left(\mathrm{~d}, 2 \mathrm{H}, J=9.1 \mathrm{~Hz}, \mathrm{H}-3^{\prime}\right.$ and H-5'), 7.13-7.25 (m, 2H, H-6 and H-7), 7.43-7.47 (m, 1H, H-4), 7.59 (s, 1H, H-2), 8.17 (s, 1H, H-8), 8.36-8.42 (m, 1H, H-5), 9.13 (s, 1H, NH), 10.47 (s, 1H, NNH). MS (ESI), $m / z=267.9(100 \%)[\mathrm{M}-\mathrm{H}]^{-}, 269.8(39 \%)[\mathrm{M}-\mathrm{H}]^{-}+2 . \mathrm{IR}(\mathrm{KBr}): 3412$, $3302,1599,1497,1433,1074,747 \mathrm{~cm}^{-1}$. Anal. calcd for $\mathrm{C}_{15} \mathrm{H}_{12} \mathrm{~N}_{3} \mathrm{Cl}$ : C, 66.79; H, 4.48; N, 15.58. Found: $\mathrm{C}, 66.45 ; \mathrm{H}, 5.14 ; \mathrm{N}, 12.11$. Mp $117-122{ }^{\circ} \mathrm{C}$ from ethyl acetate/hexane 50:50 (v/v).

5-Methoxy-3-((2-(pyridin-2-yl)hydrazineylidene)methyl)-1H-indole (34). Yield: $50 \% .{ }^{1} \mathrm{H}-\mathrm{NMR}$ $\left(\mathrm{DMSO}_{-} \mathrm{d}_{6}\right) \delta 3.82\left(\mathrm{~s}, 3 \mathrm{H}, \mathrm{OCH}_{3}\right), 6.64-6.67\left(\mathrm{~m}, 1 \mathrm{H}, \mathrm{H}-4^{\prime}\right), 6.82(\mathrm{dd}, 1 \mathrm{H}, \mathrm{Jo}=8.8, \mathrm{Jm}=2.5 \mathrm{~Hz}$, H-6), 7.15 (d, 1H, Jo = 8.2 Hz, H-6'), 7.30 (d, 1H, Jo = 8.8 Hz, H-7), 7.60 (br s, 1H, H-2), 7.63-7.66 (m, 1H, H-5') $7.74(\mathrm{~d}, 1 \mathrm{H}, J m=2.5 \mathrm{~Hz}, \mathrm{H}-4), 8.04-8.08\left(\mathrm{~m}, 1 \mathrm{H}, \mathrm{H}-3^{\prime}\right), 8.21(\mathrm{~s}, 1 \mathrm{H}, \mathrm{CH}=\mathrm{N}), 10.41(\mathrm{~s}, 1 \mathrm{H}, \mathrm{NH})$, $11.24(\mathrm{~s}, 1 \mathrm{H}, \mathrm{NNH})$. MS (ESI), $m / z=264.9(100 \%)[\mathrm{M}-\mathrm{H}]^{-}, 289.0(100 \%)[\mathrm{M}+\mathrm{Na}]^{+} . \mathrm{IR}(\mathrm{KBr}): 3439$, $3184,2998,1598,1444 \mathrm{~cm}^{-1}$. Mp $185-187^{\circ} \mathrm{C}$ from EtOH.

2-(2-((5-Methoxy-1H-indol-3-yl)methylene)hydrazineyl)quinoline (35). Yield: 50\%. ${ }^{1} \mathrm{H}-\mathrm{NMR}\left(\mathrm{DMSO}-\mathrm{d}_{6}\right)$ $\delta 3.87\left(\mathrm{~s}, 3 \mathrm{H}, \mathrm{OCH}_{3}\right), 6.84(\mathrm{dd}, 1 \mathrm{H}, \mathrm{Jo}=8.8, \mathrm{Jm}=2.6 \mathrm{~Hz}, \mathrm{H}-6), 7.20-7.24(\mathrm{~m}, 1 \mathrm{H}), 7.32(\mathrm{~d}, 1 \mathrm{H}, \mathrm{Jo}=8.8 \mathrm{~Hz}$, H-7), 7.50-7.73 (m, 5H), $7.80(\mathrm{~d}, 1 \mathrm{H}, J m=2.2 \mathrm{~Hz}, \mathrm{H}-4), 8.17(\mathrm{~d}, 1 \mathrm{H}, J o=9.2 \mathrm{~Hz}), 8.27(\mathrm{~s}, 1 \mathrm{H}, \mathrm{CH}=\mathrm{N})$, $10.96(\mathrm{~s}, 1 \mathrm{H}, \mathrm{NH}), 11.28(\mathrm{~s}, 1 \mathrm{H}, \mathrm{NNH}) . \mathrm{MS}(\mathrm{ESI}), \mathrm{m} / z=314.8(100 \%)[\mathrm{M}-\mathrm{H}]^{-}, 317.0(100 \%)[\mathrm{M}+\mathrm{Na}]^{+}$, $339.0(42 \%)[\mathrm{M}+\mathrm{H}]^{+}$. IR (KBr): 3432, 2948, 1607, 1571, $1430 \mathrm{~cm}^{-1}$. Mp 233-235 ${ }^{\circ} \mathrm{C}$ from EtOH.

7-Chloro-4-(2-((5-methoxy-1H-indol-3-yl)methylene)hydrazineyl)quinoline (36). Yield: 44\%. ${ }^{1} \mathrm{H}-\mathrm{NMR}$ $\left(\mathrm{DMSO}_{-} \mathrm{d}_{6}\right) \delta 3.86\left(\mathrm{~s}, 3 \mathrm{H}, \mathrm{OCH}_{3}\right), 6.87(\mathrm{~d}, 1 \mathrm{H}, \mathrm{Jo}=8.4 \mathrm{~Hz}, \mathrm{H}-6), 7.24-7.26(\mathrm{~m}, 1 \mathrm{H}), 7.36(\mathrm{~d}, 1 \mathrm{H}, \mathrm{Jo}=8.4 \mathrm{~Hz}$, H-7), $7.54(\mathrm{~d}, 1 \mathrm{H}, J o=8.4 \mathrm{~Hz}), 7.65-7.87(\mathrm{~m}, 3 \mathrm{H}), 8.41-8.44(\mathrm{~m}, 3 \mathrm{H}), 8.64(\mathrm{br} \mathrm{s}, 1 \mathrm{H}, \mathrm{CH}=\mathrm{N}), 11.51$ (br s, $1 \mathrm{H}, \mathrm{NNH})$. MS (ESI), $m / z=348.9(100 \%)[\mathrm{M}-\mathrm{H}]^{-}, 373.0(100 \%)[\mathrm{M}+\mathrm{Na}]^{+}, 351.0(16 \%)[\mathrm{M}+\mathrm{H}]^{+}$. IR (KBr): 3351, 3231, 1615, 1578, $1425 \mathrm{~cm}^{-1}$. Mp $>255^{\circ} \mathrm{C}$ from EtOH. 


\subsubsection{3-(2-(4-Isopropylphenyl)hydrazineylidene)isoindolin-1-one (38)}

The 3-iminoisoindolinone 37 previously prepared [47] (1 mmol, 1 eq) was dissolved in $5 \mathrm{~mL}$ of methanol, then 4-isopropylphenylhydrazine (2.4 eq) was added at room temperature. After stirring overnight, the mixture was filtered and the precipitate was purified by crystallization. Yield: $60 \%$. ${ }^{1} \mathrm{H}-\mathrm{NMR}\left(\mathrm{DMSO}-d_{6}\right) \delta 1.16\left(\mathrm{~d}, 6 \mathrm{H}, J=7.0 \mathrm{~Hz}, \mathrm{CH}\left(\underline{\mathrm{CH}_{3}}\right)_{2}\right), 2.80\left(\mathrm{ep}, 1 \mathrm{H}, J=7.0 \mathrm{~Hz}, \underline{\mathrm{CH}}\left(\mathrm{CH}_{3}\right)_{2}\right), 7.03(\mathrm{~d}$, $2 \mathrm{H}, J=8.6 \mathrm{~Hz}, \mathrm{H}-2^{\prime}$ and $\left.\mathrm{H}-6^{\prime}\right), 7.13\left(\mathrm{~d}, 2 \mathrm{H}, J=8.6 \overline{\mathrm{Hz}, \mathrm{H}}-3^{\prime}\right.$ and $\left.\mathrm{H}-5^{\prime}\right), 7.53(\mathrm{td}, 1 \mathrm{H}, J o=7.4, J m=1.1 \mathrm{~Hz}$, $\mathrm{H}-5), 7.68(\mathrm{td}, 1 \mathrm{H}, \mathrm{Jo}=7.4, \mathrm{Jm}=1.1 \mathrm{~Hz}, \mathrm{H}-6), 7.75(\mathrm{dd}, 1 \mathrm{H}, J o=7.4, J m=0.8 \mathrm{~Hz}, \mathrm{H}-4), 7.83(\mathrm{dd}, 1 \mathrm{H}$, $J o=7.4, J m=0.8 \mathrm{~Hz}, \mathrm{H}-7), 9.31(\mathrm{~s}, 1 \mathrm{H}, \mathrm{NH}), 10.72(\mathrm{~s}, 1 \mathrm{H}, \mathrm{NNH})$. ESI-MS $m / z=277.9(100 \%)[\mathrm{M}-\mathrm{NH}]^{-}$. IR (KBr): 3351, 2964, 1712, 1612, $1127 \mathrm{~cm}^{-1}$. Mp 186-187 ${ }^{\circ} \mathrm{C}$ from $\mathrm{CHCl}_{3} /$ hexane.

\subsubsection{Synthesis of 5-Bromo-3-chloro-2-((2-phenylhydrazineylidene)methyl)-1H-indoles 40 and 41}

Compound 39 (0.3 mmol, 1 eq), previously synthesized by conversion of acyclic dicarboxylic to aldehyde under Vilsmeier condition [21], was solubilized in ethanol (1 M). Catalytic amount of acetic acid and suitable arylhydrazine (1.2 eq) were added to the solution and the mixture was stirred for $4 \mathrm{~h}$ at $0^{\circ} \mathrm{C}$. Then the solvent was evaporated, and the crude product was crystalized or purified by column chromatography.

5-Bromo-3-chloro-2-((2-phenylhydrazineylidene)methyl)-1H-indole (40). Yield: 40\%. ${ }^{1} \mathrm{H}-\mathrm{NMR}\left(\mathrm{CDCl}_{3}\right)$ $\delta 6.93\left(\mathrm{t}, 1 \mathrm{H}, \mathrm{Jo}=7.4 \mathrm{~Hz}, \mathrm{H}-4^{\prime}\right), 7.12\left(\mathrm{~d}, 2 \mathrm{H}, \mathrm{Jo}=8.8, \mathrm{H}-2^{\prime}\right.$ and H-6'), $7.22(\mathrm{~d}, 1 \mathrm{H}, J o=8.8 \mathrm{~Hz}, \mathrm{H}-7)$, 7.27-7.35 (m, 3H), 7.72 (br s, 1H, CH=N), 7.82 (s, 1H, H-4), 7.86 (s, 1H, NNH), 8.71 (s, 1H, NH). MS $(\mathrm{ESI}), m / z=346.0(54 \%)[\mathrm{M}-\mathrm{H}]^{-}, 347.8(100 \%)[\mathrm{M}-\mathrm{H}]^{-}+2,349.7(25 \%)[\mathrm{M}-\mathrm{H}]^{-}+4 . \mathrm{IR}(\mathrm{KBr}): 3415$, $1630,1460 \mathrm{~cm}^{-1}$. Mp $165-170{ }^{\circ} \mathrm{C}$ from $\mathrm{CHCl}_{3} /$ hexane.

5-Bromo-3-chloro-2-((2-(4-isopropylphenyl)hydrazineylidene)methyl)-1H-indole (41). Yield: $20 \%$. ${ }^{1} \mathrm{H}-\mathrm{NMR}\left(\mathrm{DMSO}-d_{6}\right) \delta 1.16\left(\mathrm{~d}, 6 \mathrm{H}, \mathrm{Jv}=6.9 \mathrm{~Hz}, \mathrm{CH}\left(\mathrm{CH}_{3}\right)_{2}\right), 2.80\left(\mathrm{ep}, 1 \mathrm{H}, J v=6.9 \mathrm{~Hz}, \mathrm{CH}\left(\mathrm{CH}_{3}\right)_{2}\right)$, 7,07-7.12 (m, 4H, H-2' ${ }^{\prime} \mathrm{H}-3^{\prime}, \mathrm{H}-4^{\prime}, \mathrm{H}-5^{\prime}$ and H-6' $\left.), 7.28 \overline{(\mathrm{dd}, 1} \mathrm{H}, J o=8.8, J m=1.8 \mathrm{~Hz}, \mathrm{H}-6\right), \overline{7.36}(\mathrm{~d}, 1 \mathrm{H}$, $J o=8.8 \mathrm{~Hz}, \mathrm{H}-7), 7.55(\mathrm{~d}, 1 \mathrm{H}, J m=1.8 \mathrm{~Hz}, \mathrm{H}-4), 7.89(\mathrm{~s}, 1 \mathrm{H}, \mathrm{CH}=\mathrm{N}), 10.64(\mathrm{~s}, 1 \mathrm{H}, \mathrm{NH}), 11.66(\mathrm{~s}, 1 \mathrm{H}$, NNH). MS (ESI), $m / z=387.8(73 \%)[\mathrm{M}-\mathrm{H}]^{-}, 389.7(100 \%)[\mathrm{M}-\mathrm{H}]^{-}+2,391.7(26 \%)[\mathrm{M}-\mathrm{H}]^{-}+4$. IR (KBr): 3382, 2956, 1537, 1515, $1254 \mathrm{~cm}^{-1}$. Mp 140-143 ${ }^{\circ} \mathrm{C}$ from hexane/ethyl acetate 90:10 (v/v).

\subsubsection{2-(2,4-Dihydroxyquinolin-3-yl)-3H-indol-3-one (43)}

The dihydroxyquinolinedione 42 [22] (0.5 mmol, 1 eq) was mixed with indoxyl acetate (1 eq) in neat condition and heated to $120^{\circ} \mathrm{C}$. After $15 \mathrm{~min}$ the mixture was cooled and dissolved with diethyl ether. The organic solvent was decanted and evaporated obtaining the desired compound. Yield: $45 \%$. ${ }^{1} \mathrm{H}-\mathrm{NMR}\left(\mathrm{DMSO}-d_{6}\right) \delta 6.90(\mathrm{t}, 1 \mathrm{H}, J o=7.4 \mathrm{~Hz}), 7.04-7.12(\mathrm{~m}, 4 \mathrm{H}), 7.38(\mathrm{~d}, 1 \mathrm{H}, J o=8.3 \mathrm{~Hz}), 7.58(\mathrm{t}, 1 \mathrm{H}$, $J o=7.7 \mathrm{~Hz}), 7.70(\mathrm{~d}, 1 \mathrm{H}, J o=7.7 \mathrm{~Hz}), 10.97(\mathrm{~s}, 1 \mathrm{H}, \mathrm{OH}), 11.05(\mathrm{~s}, 1 \mathrm{H}, \mathrm{OH}) . \mathrm{MS}(\mathrm{ESI}), m / z=289.8(100 \%)$ $[\mathrm{M}-\mathrm{H}]^{-}$. IR (KBr): 3385, 1713, 1673, $1614 \mathrm{~cm}^{-1}$. Mp 90-92 ${ }^{\circ} \mathrm{C}$.

\subsection{Biological Assays}

All assays were performed in 96-well plates (Greiner Bio-One, Kremsmünster, Austria) using an Infinite M1000 Pro plate reader (Tecan, Cernusco s.N., Italy). Inhibition data were obtained as mean $\pm \mathrm{SD}$ (for single concentration points) or mean \pm SEM from three independent experiments (for $\mathrm{IC}_{50} \mathrm{~s}$ ), using Prism (GraphPad Prism version 5.00 for Windows, GraphPad Software, San Diego, CA, USA).

\subsubsection{Inhibition of $A \beta_{40}$ Self-Aggregation}

Assay of aggregation of $\mathrm{A} \beta_{40}$ (EzBiolab, Carmel, IN, USA) was performed as described [25], using $2 \%$ of 1,1,1,3,3,3-hexafluoro-2-propanol as aggregation enhancer and spectrofluorimetric detection of thioflavin $\mathrm{T}$ fluorescence as the probe of amyloid aggregation. 


\subsubsection{Inhibition of Cholinesterases}

Inhibition of human recombinant AChE (2770 U/mg) or BChE from human serum (50 U/mg; both from Sigma Aldrich, St. Louis, MO, USA), was determined as described [48], by applying the Ellman's spectrophotometric method to a 96-well plate procedure.

\subsubsection{Inhibition of Monoamine Oxidases}

Inhibition of human recombinant monoamine oxidases A (250 U/mg) and B (59 U/mg; microsomes from baculovirus infected insect cells; Sigma Aldrich) was determined as already described [48], measuring the fluorescence of 4-hydroxyquinoline produced by the oxidative deamination of substrate kynuramine.

\subsection{In Vitro Cell-Based Assays}

Compounds for bacterial media were purchased from CondaLab (Madrid, Spain). M9 minimal medium; for $100 \mathrm{~mL}$ : $10 \mathrm{~mL}$ salts $10 \times\left(0.68 \mathrm{~g} \mathrm{Na}_{2} \mathrm{HPO}_{4}, 0.30 \mathrm{~g} \mathrm{KH}_{2} \mathrm{PO}_{4}, 0.05 \mathrm{~g} \mathrm{NaCl}, 0.10 \mathrm{~g} \mathrm{NH} 4 \mathrm{Cl}\right)$, $0.2 \mathrm{~mL} \mathrm{1M} \mathrm{MgSO}, 0.2 \mathrm{~mL} 50 \mathrm{mM} \mathrm{CaCl}_{2}, 2.5 \mathrm{~mL} \mathrm{20 \%} \mathrm{glucose} \mathrm{and} 87.1 \mathrm{~mL} \mathrm{H}_{2} \mathrm{O}$.

\subsubsection{Tau Aggregation Inhibition Assay in Bacterial Cells}

Escherichia coli competent cells BL21 (DE3) were transformed with pTARA containing the RNA-polymerase gen of T7 phage (T7RP) under the control of the promoter PBAD and pRKT42 vector encoding four repeats of tau protein in two inserts. Because of the addition of the initiation codon ATG in front of gene, the over-expressed protein contains an additional methionine residue at its $\mathrm{N}$ terminus. Tau anti-aggregating activities of the target compounds were assessed in E. coli cells, as previously described [27-29]. M9 minimal medium (10 mL) containing $0.5 \%$ of glucose, $100 \mu \mathrm{g} / \mathrm{mL}$ of ampicillin and $12.5 \mu \mathrm{g} / \mathrm{mL}$ of chloramphenicol was inoculated with a colony of BL21 (DE3) cells bearing the plasmids. To fresh M9 minimal medium containing $0.5 \%$ of glucose, $50 \mu \mathrm{g} / \mathrm{mL}$ of ampicillin, $12.5 \mu \mathrm{g} / \mathrm{mL}$ of chloramphenicol, and $250 \mu \mathrm{M}$ of ThS, the volume of overnight culture necessary to get a 1:500 dilution was added. The cultures were grown at $37^{\circ} \mathrm{C}$ and $250 \mathrm{rpm}$ overnight until cell density reached $\mathrm{OD}_{600}=0.6$. A volume of $980 \mu \mathrm{L}$ of the cultures was transferred into $1.5 \mathrm{~mL}$ Eppendorf tubes that contained $10 \mu \mathrm{L}$ of a solution of the target compound in DMSO and $10 \mu \mathrm{L}$ of arabinose at $25 \%$, leading to a final inhibitor concentration of $10 \mu \mathrm{M}$. The resulting cultures were grown at $37^{\circ} \mathrm{C}$ and $1400 \mathrm{rpm}$ with a Thermomixer (Eppendorf, Hamburg, Germany) overnight. The same amount of DMSO without the target compound was added to the sample as a negative control (maximal amount of tau), whereas non-induced samples (in the absence of arabinose) were prepared as positive controls (absence of tau), and to assess the potential intrinsic toxicity of the target compounds. In addition, the absorbance at $600 \mathrm{~nm}$ of these samples was assessed to confirm the correct bacterial growth, discarding potential intrinsic toxicity of compounds. To determine the $\mathrm{IC}_{50}$ values, the same protocol was followed but only modifying the initial concentration of compounds. In order to use different final concentrations of compound, we performed a dilutions banc from a stock solution of $100 \mathrm{mM}$ in MilliQ $\mathrm{H}_{2} \mathrm{O}$.

\subsubsection{Thioflavin S Steady-State Fluorescence}

ThS fluorescence and absorbance were tracked using a DTX 800 plate reader Multimode Detector equipped with a Multimode Analysis Software (Beckman-Coulter, Indianapolis, IN, USA). Filters of $430 / 35$ and $485 / 20 \mathrm{~nm}$ were used for the excitation and emission wavelengths, respectively. 535/25 nm filters were also used for the absorbance determination. It should be stressed that ThS fluorescence normalization was carried out considering as $100 \%$ the ThS fluorescence of the bacterial cells expressing tau in the absence of compounds and $0 \%$ the ThS fluorescence of the bacterial cells non-expressing tau. 


\subsection{Computational Studies}

For each compound a suitable three-dimensional structure was built by employing MacroModel [49] for energy minimization based on OPLS_2005 force field and by setting a maximum of 100 bioactive conformers as set in ConfGen [50]. Ligprep [51] was employed for determining possible protonation states at physiological $\mathrm{pH}$. The pharmacophore and atom-based 3D-QSAR models were then derived by using Phase [41] after entering the prepared structures along with their respective biological activity values. The ligands were thus designated as actives or inactives based on the $\mathrm{IC}_{50}$ threshold equal to $100 \mu \mathrm{M}$. Flexible ligands alignment was automatically performed by Phase. The maximum and minimum number of features was set to 7 and 4, respectively, with a tolerance sphere of $2 \AA$, provided that at least $50 \%$ of actives must match. Excluded volumes were also accounted to better discern inactives for which the clash value was set to 1 and the minimum distance between active surface and excluded volume was set to $1 \AA$. In doing that, 13 different pharmacophore hypotheses were generated sorted on the values of the Phase Hypo Score, which is a linear combination of different contributes related with site, volume, vector and selectivity scores [52,53].

3D-QSAR model was based on partial least squares (PLS) regression statistics on grid descriptors (that are HBA, HBD, hydrophobic interactions and electron withdrawing effects) sampled on a lattice with a spacing of $1 \AA$. The number of optimal PLS factors was equal to 4 given that the increase of $\mathrm{q}^{2}$ was not higher than $5 \%$ by adding a further component. For the sake of clarity, only compounds with experimentally measured $\mathrm{IC}_{50}$ values were included in the analysis.

\section{Conclusions}

Building on our previous results, we progressed the decoration of the isatin scaffold to prepare a large number of derivatives displaying antiamyloidogenic activity over a wide range of potency. Five out of the 36 new compounds displayed $\mathrm{IC}_{50}$ values in the low to submicromolar range, being $N$-substituted isatins $9\left(\mathrm{IC}_{50}=0.95 \mu \mathrm{M}\right), \mathbf{1 8}(1.3 \mu \mathrm{M})$ and $19(1.6 \mu \mathrm{M})$ the most potent inhibitors of $\mathrm{A} \beta$ aggregation. This feature was in full agreement with our previous observations [19] of the enhancing effect brought by $N$-substitution at the isatin nitrogen, as herein confirmed by comparing the pairs 6-7 and 8-9. The screening of selected compounds in tau overexpressing cells allowed to disclose an interesting inhibitory activity against tau aggregation, although no apparent correlation was found between this activity and in vitro inhibition of $\mathrm{A} \beta$ aggregation. Among the tested compounds, isatin 3-phenylhydrazone 5 scored the best activity $(4.6 \mu \mathrm{M})$. Taking into account our previous observations assessing the low intrinsic toxicity of isatin scaffold in different cellular assays [17-19], we may conclude that this class of molecules has the potential for further development as antiamyloidogenic agents with safe cytotoxic profile.

In this paper, we also expanded the exploration of SAR to indole derivatives, most of them bearing the arylhydrazone moiety (compounds 28-36) and resulting with few exceptions in good inhibitors of $A \beta$ aggregation. Other structural variations based on molecular simplification or shift of hydrazone substituent were not favorable for activity.

In the perspective of discovering new multitarget agents for $\mathrm{AD}$, we selected some candidates for their evaluation as inhibitors of AChE and MAOs, two target enzymes involved in neurodegenerative diseases. Satisfactorily, several isatin and indole derivatives displayed interesting MAO inhibition, overall selective (compounds $9, \mathbf{1 1}, \mathbf{1 3}$ ) towards the B isoform. Unsurprisingly, isatin hydrazone 5 resulted a potent MAO A inhibitor, since the MAO activity has been reported for different isatin derivatives [35-37]. Conversely, we found indole derivative $\mathbf{3 2}$ as the most potent, although nonselective, $\mathrm{MAO}$ inhibitor with $\mathrm{IC}_{50}$ values of 0.34 and $0.23 \mu \mathrm{M}$ for MAO A and MAO B, respectively. Even considering its good potency in inhibition of $\mathrm{A} \beta$ aggregation $(8.4 \mu \mathrm{M})$, the multitarget profile of 32 as dual $\mathrm{MAO} / \mathrm{A} \beta$ aggregation inhibitor deserves further insights, mainly aiming to improve A/B selectivity.

The data obtained from in vitro tests of inhibition of $A \beta$ aggregation prompted us to derive a pharmacophore model for $\mathrm{A} \beta$ antiaggregating activity. The molecular shape, lipophilicity of 
substituents, and the substitution at the isatin nitrogen appeared to be the main determinants for antiamyloidogenic activity. The combined approach based on pharmacophore and 3D-QSAR models allowed us to furnish more confident predictions thus allowing to better address the rational design of new active and more promising compounds.

Supplementary Materials: The following are available online, Chemical structures, SMILES codes, and inhibition values of 93 previously published compounds constituting the training set.

Author Contributions: M.C. and C.D.A. conceived the work; M.C., R.S., S.C. and O.N. designed the experiments; R.P., N.G., M.C., M.d.C., L.P. and A.E. performed the experiments; R.P., N.G., M.C. and R.S. wrote the paper; all authors analysed the data and revised the manuscript. All authors have read and agreed to the published version of the manuscript.

Funding: M.C. and L.P. acknowledge the financial support from Italian Ministry for Education and Research (Fondo di Finanziamento per le Attività Base di Ricerca, FFABR 2017).

Conflicts of Interest: The authors declare no conflict of interest.

\section{References}

1. Alzheimer's Association. 2020 Alzheimer's disease facts and figures. Alzheimers Dement. 2020, 16, 391-460. [CrossRef]

2. Dementia in Europe Yearbook 2019. Available online: https://www.alzheimer-europe.org (accessed on 21 September 2020).

3. Cummings, J.; Lee, G.; Ritter, A.; Sabbagh, M.; Zhong, K. Alzheimer's disease drug development pipeline: 2020. Alzheimers Dement. 2020, 6, e12050. [CrossRef]

4. Aisen, P.S.; Cummings, J.; Doody, R.; Kramer, L.; Salloway, S.; Selkoe, D.J.; Sims, J.; Sperling, R.A.; Vellas, B. The future of anti-amyloid trials. J. Prev. Alzheimers Dis. 2020, 7, 146-151. [CrossRef] [PubMed]

5. Lozupone, M.; Solfrizzi, V.; D’Urso, F.; Di Gioia, I.; Sardone, R.; Dibello, V.; Stallone, R.; Liguori, A.; Ciritella, C.; Daniele, A.; et al. Anti-amyloid- $\beta$ protein agents for the treatment of Alzheimer's disease: An update on emerging drugs. Expert Opin. Emerg. Drugs 2020, 25, 319-335. [CrossRef] [PubMed]

6. Moussa-Pacha, N.M.; Abdin, S.M.; Omar, H.A.; Alniss, H.; Al-Tel, T.H. BACE1 inhibitors: Current status and future directions in treating Alzheimer's disease. Med. Res. Rev. 2020, 40, 339-384. [CrossRef] [PubMed]

7. Uddin, M.S.; Kabir, M.T.; Rahman, M.S.; Behl, T.; Jeandet, P.; Ashraf, G.M.; Najda, A.; Bin-Jumah, M.N.; El-Seedi, H.R.; Abdel-Daim, M.M. Revisiting the amyloid cascade hypothesis: From anti-A $\beta$ therapeutics to auspicious new ways for Alzheimer's disease. Int. J. Mol. Sci. 2020, 21, 5858. [CrossRef]

8. VandeVrede, L.; Boxer, A.L.; Polydoro, M. Targeting tau: Clinical trials and novel therapeutic approaches. Neurosci. Lett. 2020, 731, 134919. [CrossRef]

9. Yadikar, H.; Torres, I.; Aiello, G.; Kurup, M.; Yang, Z.; Lin, F.; Kobeissy, F.; Yost, R.; Wang, K.K. Screening of tau protein kinase inhibitors in a tauopathy-relevant cell-based model of tau hyperphosphorylation and oligomerization. PLOS ONE 2020, 15, e0224952. [CrossRef]

10. González, J.F.; Alcántara, A.R.; Doadrio, A.L.; Sánchez-Montero, J.M. Developments with multi-target drugs for Alzheimer's disease: An overview of the current discovery approaches. Expert Opin. Drug Discov. 2019, 14, 879-891. [CrossRef]

11. Catto, M.; Berezin, A.A.; Lo Re, D.; Loizou, G.; Demetriades, M.; De Stradis, A.; Campagna, F.; Koutentis, P.A.; Carotti, A. Design, synthesis and biological evaluation of benzo[e][1,2,4]triazin-7(1H)-one and [1,2,4]-triazino [5,6,1-jk]carbazol-6-one derivatives as dual inhibitors of beta-amyloid aggregation and acetyl/butyryl cholinesterase. Eur. J. Med. Chem. 2012, 58, 84-97. [CrossRef]

12. Mariano, M.; Schmitt, C.; Miralinaghi, P.; Catto, M.; Hartmann, R.W.; Carotti, A.; Engel, M. First selective dual inhibitors of tau phosphorylation and beta-amyloid aggregation, two major pathogenic mechanisms in Alzheimer's disease. ACS Chem. Neurosci. 2014, 5, 1198-1202. [CrossRef] [PubMed]

13. Tonelli, M.; Catto, M.; Tasso, B.; Novelli, F.; Canu, C.; Iusco, G.; Pisani, L.; De Stradis, A.; Denora, N.; Sparatore, A.; et al. Multitarget therapeutic leads for Alzheimer's disease: Quinolizidinyl derivatives of biand tri-cyclic systems as dual inhibitors of cholinesterases and A $\beta$ aggregation. ChemMedChem 2015, 10, 1040-1053. [CrossRef] [PubMed] 
14. Domínguez, J.L.; Fernández-Nieto, F.; Brea, J.M.; Catto, M.; Paleo, M.R.; Porto, S.; Sardina, F.J.; Castro, M.; Pisani, L.; Carotti, A.; et al. 8-Aminomethyl-7-hydroxy-4-methylcoumarins as multitarget leads for Alzheimer's disease. ChemistrySelect 2016, 1, 2742-2749. [CrossRef]

15. Catto, M.; Aliano, R.; Carotti, A.; Cellamare, S.; Palluotto, F.; Purgatorio, R.; De Stradis, A.; Campagna, F. Design, synthesis and biological evaluation of indane- 2-arylhydrazinylmethylene-1,3-diones and indol-2-aryldiazenylmethylene-3-ones as $\beta$-amyloid aggregation inhibitors. Eur. J. Med. Chem. 2010, 45, 1359-1366. [CrossRef] [PubMed]

16. Campagna, F.; Catto, M.; Purgatorio, R.; Altomare, C.D.; Carotti, A.; De Stradis, A.; Palazzo, G. Synthesis and biophysical evaluation of arylhydrazono-1H-2-indolinones as $\beta$-amyloid aggregation inhibitors. Eur. J. Med. Chem. 2011, 46, 275-284. [CrossRef] [PubMed]

17. Pisani, L.; De Palma, A.; Giangregorio, N.; Miniero, D.V.; Pesce, P.; Nicolotti, O.; Campagna, F.; Altomare, C.D.; Catto, M. Mannich base approach to 5-methoxyisatin 3-(4-isopropylphenyl)hydrazone: A water-soluble prodrug for a multitarget inhibition of cholinesterases, beta-amyloid fibrillization and oligomer-induced cytotoxicity. Eur. J. Pharm. Sci. 2017, 109, 381-388. [CrossRef]

18. Catto, M.; Arnesano, F.; Palazzo, G.; De Stradis, A.; Calò, V.; Losacco, M.; Purgatorio, R.; Campagna, F. Investigation on the influence of (Z)-3-(2-(3-chlorophenyl)hydrazono)-5,6-dihydroxyindolin-2-one (PT2) on $\beta$-amyloid(1-40) aggregation and toxicity. Archiv. Biochem. Biophys. 2014, 560, 73-82. [CrossRef]

19. Purgatorio, R.; de Candia, M.; De Palma, A.; De Santis, F.; Pisani, L.; Campagna, F.; Cellamare, S.; Altomare, C.D.; Catto, M. Insights into structure-activity relationships of 3-arylhydrazonoindolin-2-one derivatives for their multitarget activity on $\beta$-amyloid aggregation and neurotoxicity. Molecules 2018, $23,1544$. [CrossRef]

20. Crestini, C.; Saladino, R. A new efficient and mild synthesis of 2-oxindoles by one-pot Wolff-Kishner like reduction of isatin derivatives. Synth. Commun. 1994, 24, 2835-2841. [CrossRef]

21. Majo, V.J.; Perumal, P.T. One-pot synthesis of heterocyclic $\beta$-chlorovinyl aldehydes using Vilsmeier reagent. J. Org. Chem. 1996, 61, 6523-6525. [CrossRef]

22. Kappe, T.; Lender, E.; Ziegler, E. Synthesen yon Heterocyclen, 118. Mitt.: Über Reaktionen mit heterocyclischen Aminalen. Monats. Chem. 1968, 66, 2157-2166. [CrossRef]

23. Ryabova, S.Y.; Alekseeva, L.M.; Granik, V.G. Acetals of acid lactams and amides. 70. Reactions of 2-aminomethyleneindolin-3-one with $\mathrm{CH}$-acids. Synthesis of substituted pyrrolo[1,2-a]indoles. Chem. Heterocycl. Compd. 1991, 27, 960-965. [CrossRef]

24. Angelova, V.T.; Rangelov, M.; Todorova, N.; Dangalov, M.; Andreeva-Gateva, P.; Kondeva-Burdina, M.; Karabeliov, V.; Shivachev, B.; Tchekalarova, J. Discovery of novel indole-based aroylhydrazones as anticonvulsants: Pharmacophore-based design. Bioorg. Chem. 2019, 90, 103028. [CrossRef] [PubMed]

25. Purgatorio, R.; de Candia, M.; Catto, M.; Carrieri, A.; Pisani, L.; De Palma, A.; Toma, M.; Ivanova, O.A.; Voskressensky, L.G.; Altomare, C.D. Investigating 1,2,3,4,5,6-hexahydroazepino[4,3-b]indole as scaffold of butyrylcholinesterase-selective inhibitors with additional neuroprotective activities for Alzheimer's disease. Eur. J. Med. Chem. 2019, 177, 414-424. [CrossRef] [PubMed]

26. Shiells, H.; Schelter, B.O.; Bentham, P.; Baddeley, T.C.; Rubino, C.M.; Ganesan, H.; Hammel, J.; Vuksanovic, V.; Staff, R.T.; Murray, A.D.; et al. Concentration-dependent activity of Hydromethylthionine on clinical decline and brain atrophy in a randomized controlled trial in behavioral variant frontotemporal dementia. J. Alzheimers Dis. 2020, 75, 501-519. [CrossRef] [PubMed]

27. Pouplana, S.; Espargaró, A.; Galdeano, C.; Viayna, E.; Sola, I.; Ventura, S.; Muñoz-Torrero, D.; Sabate, R. Thioflavin-S staining of bacterial inclusion bodies for the fast, simple, and inexpensive screening of amyloid aggregation inhibitors. Curr. Med. Chem. 2014, 21, 1152-1159. [CrossRef]

28. Espargaró, A.; Medina, A.; Di Pietro, O.; Muñoz-Torrero, D.; Sabate, R. Ultra rapid in vivo screening for anti-Alzheimer anti-amyloid drugs. Sci. Rep. 2016, 6, 23349. [CrossRef]

29. Espargaró, A.; Pont, C.; Gamez, P.; Muñoz-Torrero, D.; Sabate, R. Amyloid pan-inhibitors: One family of compounds to cope with all conformational diseases. ACS Chem. Neurosci. 2019, 10, 1311-1317. [CrossRef]

30. Farina, R.; Pisani, L.; Catto, M.; Nicolotti, O.; Gadaleta, D.; Denora, N.; Soto-Otero, R.; Mendez-Alvarez, E.; Passos, C.S.; Muncipinto, G.; et al. Structure-based design and optimization of multitarget-directed 2H-chromen-2-one derivatives as potent inhibitors of monoamine oxidase B and cholinesterases. J. Med. Chem. 2015, 58, 5561-5578. [CrossRef] 
31. Pisani, L.; Farina, R.; Catto, M.; Iacobazzi, R.; Nicolotti, O.; Cellamare, S.; Mangiatordi, G.F.; Denora, N.; Soto-Otero, R.; Siragusa, L.; et al. Exploring basic tail modifications of coumarin-based dual acetylcholinesterase-monoamine oxidase B inhibitors: Identification of water-soluble, brain-permeant neuroprotective multitarget agents. J. Med. Chem. 2016, 59, 6791-6806. [CrossRef]

32. Pisani, L.; Iacobazzi, R.; Catto, M.; Rullo, M.; Farina, R.; Denora, N.; Cellamare, S.; Altomare, C.D. Investigating alkyl nitrates as nitric oxide releasing precursors of multitarget acetylcholinesterase-monoamine oxidase $\mathrm{B}$ inhibitors. Eur. J. Med. Chem. 2019, 161, 292-309. [CrossRef] [PubMed]

33. Medvedev, A.; Buneeva, O.; Gnedenko, O.; Ershov, P.; Ivanov, A. Isatin, an endogenous nonpeptide biofactor: A review of its molecular targets, mechanisms of actions, and their biomedical implications. Biofactors 2018, 44, 95-108. [CrossRef] [PubMed]

34. Phogat, P.; Singh, P. A mini review on central nervous system potential of isatin derivatives. Cent. Nerv. Syst. Agents Med. Chem. 2015, 15, 28-31. [CrossRef] [PubMed]

35. Manley-King, C.I.; Bergh, J.J.; Petzer, J.P. Inhibition of monoamine oxidase by selected C5- and C6-substituted isatin analogues. Bioorg. Med. Chem. 2011, 19, 261-274. [CrossRef]

36. Cheng, K.; Li, S.; Lv, X.; Tian, Y.; Kong, H.; Huang, X.; Duan, Y.; Han, J.; Xie, Z.; Liao, C. Design, synthesis and biological evaluation of novel human monoamine oxidase B inhibitors based on a fragment in an X-ray crystal structure. Bioorg. Med. Chem. Lett. 2019, 29, 1012-1018. [CrossRef]

37. Vishnu, M.S.; Pavankumar, V.; Kumar, S.; Raja, A.S. Experimental and computational evaluation of piperonylic acid derived hydrazones bearing isatin moieties as dual inhibitors of cholinesterases and monoamine oxidases. ChemMedChem 2019, 14, 1359-1376. [CrossRef]

38. Martínez-Campos, Z.; Pastor, N.; Pineda-Urbina, K.; Gómez-Sandoval, Z.; Fernández-Zertuche, M.; Razo-Hernández, R.S. In silico structure-based design of GABAB receptor agonists using a combination of docking and QSAR. Chem. Biol. Drug Des. 2019, 94, 1782-1798. [CrossRef]

39. Rodríguez-Lozada, J.; Tovar-Gudiño, E.; Guevara-Salazar, J.A.; Razo-Hernández, R.S.; Santiago, Á.; Pastor, N.; Fernández-Zertuche, M. QSAR and molecular docking studies of the inhibitory activity of novel heterocyclic GABA analogues over GABA-AT. Molecules 2018, 23, 2984. [CrossRef]

40. Maldonado-Santiago, M.; Santiago, Á.; Pastor, N.; Alvarez, L.; Razo-Hernández, R.S. Isatin derivatives as DNA minor groove-binding agents: A structural and theoretical study. Struct. Chem. 2020, 31, 1289-1307. [CrossRef]

41. Phase; Schrödinger, LLC: New York, NY, USA, 2018.

42. Kerzare, D.; Chikhale, R.; Bansode, R.; Amnerkar, N.; Karodia, N.; Paradkar, A.; Khedekar, P. Design, synthesis, pharmacological evaluation and molecular docking studies of substituted oxadiazolyl-2-oxoindolinylidene propane hydrazide derivatives. J. Braz. Chem. Soc. 2016, 27, 1998-2010. [CrossRef]

43. Liang, C.; Xia, J.; Lei, D.; Li, X.; Yao, Q.; Gao, J. Synthesis, in vitro and in vivo antitumor activity of symmetrical bis-Schiff base derivatives of isatin. Eur. J. Med. Chem. 2014, 74, 742-750. [CrossRef] [PubMed]

44. Zheng, J.; Li, Y.; Cui, Y.; Jia, J.; Ye, Q.; Han, L.; Gao, J. Isatin-phenylhydrazone dyes and boron complexes with large Stokes shifts: Synthesis and solid-state fluorescence characteristics. Tetrahedron 2015, 71, 3802-3809. [CrossRef]

45. Tehrani, K.H.M.E.; Zadeh, M.E.; Mashayekhi, V.; Hashemi, M.; Kobarfard, F.; Gharebaghi, F.; Mohebbi, S. Synthesis, antiplatelet activity and cytotoxicity assessment of indole-based hydrazone derivatives. Iran. J. Pharm. Res. 2015, 14, 1077-1086. [CrossRef]

46. Hooper, M.; Pitkethly, W.N. 2-Arylmethylideneindolin-3-ones: Stereochemistry and reduction with sodium borohydride. J. Chem. Soc. 1972, 1606-1613. [CrossRef]

47. Luzyanin, K.V.; Kukushkin, V.Y.; Kopylovich, M.N.; Nazarov, A.A.; Galanski, M.; Pombeiro, A.J.L. Novel and mild route to phthalocyanines and 3-iminoisoindolin1-ones via N,N-diethylhydroxylamine-promoted conversion of phthalonitriles and a dramatic solvent-dependence of the reaction. Adv. Synth. Catal. 2008, 350, 135-142. [CrossRef]

48. Bolognino, I.; Giangregorio, N.; Pisani, L.; de Candia, M.; Purgatorio, R.; Tonazzi, A.; Altomare, C.D.; Cellamare, S.; Catto, M. A prospective repurposing of dantrolene as a multitarget agent for Alzheimer's disease. Molecules 2019, 24, 4298. [CrossRef]

49. MacroModel; Schrödinger, LLC: New York, NY, USA, 2018. 
50. Watts, K.S.; Dalal, P.; Murphy, R.B.; Sherman, W.; Friesner, R.A.; Shelley, J.C. ConfGen: A conformational search method for efficient generation of bioactive conformers. J. Chem. Inf. Model. 2010, 50, 534-546. [CrossRef] [PubMed]

51. LigPrep; Schrödinger, LLC: New York, NY, USA, 2018.

52. Dixon, S.L.; Smondyrev, A.M.; Knoll, E.H.; Rao, S.N.; Shaw, D.E.; Friesner, R.A. PHASE: A new engine for pharmacophore perception, 3D QSAR model development, and 3D database screening: 1. Methodology and preliminary results. J. Comput. Aided Mol. Des. 2006, 20, 647-671. [CrossRef] [PubMed]

53. Dixon, S.L.; Smondyrev, A.M.; Rao, S.N. PHASE: A novel approach to pharmacophore modeling and 3D database searching. Chem. Biol. Drug Des. 2006, 67, 370-372. [CrossRef] [PubMed]

Sample Availability: Samples of the compounds 1-45 are available from the authors

Publisher's Note: MDPI stays neutral with regard to jurisdictional claims in published maps and institutional affiliations.

(C) 2020 by the authors. Licensee MDPI, Basel, Switzerland. This article is an open access article distributed under the terms and conditions of the Creative Commons Attribution (CC BY) license (http://creativecommons.org/licenses/by/4.0/). 